\title{
The use of $\gamma$-rays analysis by HPGe detector to assess the gross alpha and beta activities in waters
}

\author{
M.F.S. Casagrande, D.M. Bonotto* \\ Departamento de Petrologia e Metalogenia, Universidade Estadual Paulista (UNESP), Av. 24-A No. 1515, C.P. 178, CEP 13506-900 Rio Claro, São Paulo, Brazil
}

\section{H I G H L I G H T S}

- Screening of gross alpha and beta activities in waters.

- Gamma rays analysis with HPGe detector.

- Non-destructive essay.

- Application to different groundwater samples.

- Enhanced radioactivity levels in Brazilian aquifers.

\section{A R T I C L E I N F O}

\section{Keywords:}

Gross alpha and beta

$\gamma$-rays analysis

HPGe detector

Groundwater radioactivity

Brazilian aquifer system

\begin{abstract}
A B S T R A C T
This paper describes an alternative method for evaluating gross alpha and beta radioactivity in waters by using $\gamma$ rays analysis performed with hyper-pure germanium detector (HPGe). Several gamma emissions related to $\alpha$ and $\beta$ - decays were used to provide the activity concentration data due to natural radionuclides commonly present in waters like ${ }^{40} \mathrm{~K}$ and those belonging to the ${ }^{238} \mathrm{U}$ and ${ }^{232} \mathrm{Th}$ decay series. The most suitable gamma emissions related to $\beta$ - decays were ${ }^{214} \mathrm{Bi}\left(1120.29 \mathrm{keV},{ }^{238} \mathrm{U}\right.$ series $)$ and ${ }^{208} \mathrm{Tl}\left(583.19 \mathrm{keV},{ }^{232} \mathrm{Th}\right.$ series $)$ as the equation in activity concentration yielded values compatible to those generated by the formula taking into account the detection efficiency. The absence of isolated and intense $\gamma$-rays peaks associated to $\alpha$ decays limited the choice to ${ }^{226} \mathrm{Ra}\left(186.21 \mathrm{keV},{ }^{238} \mathrm{U}\right.$ series$)$ and ${ }^{224} \mathrm{Ra}\left(240.99 \mathrm{keV},{ }^{232} \mathrm{Th}\right.$ series). In these cases, it was adopted appropriate correction factors involving the absolute intensities and specific activities for avoiding the interferences of other $\gamma$-rays energies. The critical level of detection across the $186-1461 \mathrm{keV}$ energy region corresponded to 0.010 , $0.023,0.038,0.086$, and $0.042 \mathrm{~Bq} / \mathrm{L}$, respectively, for ${ }^{226} \mathrm{Ra},{ }^{224} \mathrm{Ra},{ }^{208} \mathrm{Tl},{ }^{214} \mathrm{Bi}$ and ${ }^{40} \mathrm{~K}$. It is much lower than the WHO guideline reference value for gross alpha $(0.5 \mathrm{~Bq} / \mathrm{L})$ and beta $(1.0 \mathrm{~Bq} / \mathrm{L})$ in waters. The method applicability was checked by the analysis of groundwater samples from different aquifer systems occurring in the Brazilian states of São Paulo, Minas Gerais and Mato Grosso do Sul. The waters exhibit very different chemical composition and the samples with the highest radioactivity levels were those associated with lithotypes possessing enhanced uranium and thorium levels. The technique allowed directly discard the ${ }^{40} \mathrm{~K}$ contribution to the gross beta activity as potassium is an essential element for humans.
\end{abstract}

\section{Introduction}

The radiological characterization of drinking waters has been a topic of concern of several organizations worldwide, mainly due to the hazard effects into human health caused by the exposure to natural radionuclides present in the hydrosphere (Cantor, 1997; Hopke et al., 2000).

The chemical and radiological groundwater quality is associated to the geochemical context of the related aquifers. Under this perspective, it has been recognized the importance of the disintegration of ${ }^{40} \mathrm{~K}$ and a large number of natural radionuclides belonging to the ${ }^{238} \mathrm{U},{ }^{235} \mathrm{U}$ and ${ }^{232}$ Th decay series. Some rock-types contain relatively high concentrations of uranium and thorium, such as granites and alkaline rocks. Potassium is a major element in many common minerals like feldspars, despite the abundance of the radioactive ${ }^{40} \mathrm{~K}$ is only $0.012 \%$ (Heier and Billings, 1969; Rogers and Adams, 1969a, 1969b).

Therefore, many countries have established guidance levels for ingestion of radionuclides in drinking water. WHO (2011) proposed an effective dose of $0.1 \mathrm{mSv}$ as an annual limiting value based on the ingestion of 2 liters of water per day. WHO (2011) has also recommended

\footnotetext{
* Corresponding author.

E-mail address: dbonotto@rc.unesp.br (D.M. Bonotto).
} 
maximum activity concentration values for gross alpha $(0.5 \mathrm{~Bq} / \mathrm{L})$ and beta $(1.0 \mathrm{~Bq} / \mathrm{L})$ in waters. More sophisticated and time-consuming procedures for determining the radionuclides content should be adopted when the results of a screening are positive (WHO, 2011).

Several techniques and detectors are available for determining the radioactivity in waters, including the gross alpha and beta activity measurements. The use of different approaches sometimes imply on debates and discussions due to uncertainties associated to such measurements. Precipitation and co-precipitation procedures relying on ISO (9696/9697) and EPA methods are examples of sample preparation processes that must be combined to detection systems, such as scintillation, flow proportional, and liquid scintillation counting. Each technique has advantages and disadvantages in terms of efficiency, $\alpha / \beta$ spillover, self absorption, cost and time demand (Jobbágy et al., 2010). Bonotto et al. (2009) suggested a combined gamma and alpha spectrometric technique for gross beta and alpha readings, respectively. A $\gamma$ rays $\mathrm{NaI}(\mathrm{Tl})$ well-type scintillaton detector was used to the indirect determination of the beta emissions as occur reduction of the absorption effects caused by the natural salinity present in the water samples. Some disadvantages of the method are the non-simultaneous readings and the sample destruction due to evaporation until dryness and counting of the residue deposited on a planchet. Jobbágy et al. (2010) inserted this combined technique in their Table 2 together other methods available for determining gross alpha and beta activities. Jobbágy et al., $(2014,2015)$ also described the results of a European interlaboratory comparison (ILC) on gross alpha/beta activity determination that only included the most common standard methods, based on direct evaporation, co-precipitation and liquid scintillation counting. Therefore, the combined gamma/alpha spectrometric technique described by Bonotto et al. (2009) and other methods were not included in the ILC held by Jobbágy et al., (2014, 2015), despite their usefulness in radiological studies focusing different aquifer systems, for instance, those performed by Bonotto and Bueno (2008) and Bonotto (2011).

Semiconductor materials have been developed during the 60's and used for gamma radiation and charged particles detection, such as high energy electrons, protons, alpha and beta particles, etc. Hyper-pure germanium gamma rays detector (HPGe) is an example of this technology and its high spectral resolution is a very important aspect when compared with that of the $\mathrm{NaI}(\mathrm{Tl})$ scintillator (Hossain et al., 2012). This characteristic is directly associated with the capability of separation of two adjacent energy peaks and unambiguous nuclide identification.

This paper describes a method using a gamma spectrometric system associated with a coaxial HPGe detector for the characterization of gross alpha and beta activities in drinking waters. It is as a step forward of the analytical approach reported by Bonotto et al. (2009) as describes the usefulness of the high resolution $\gamma$-rays spectrometry with HPGe on providing gross alpha/beta activities in waters. The analysis of groundwater samples from different aquifer systems in the Brazilian states of São Paulo, Minas Gerais and Mato Grosso do Sul is also reported here.

The experiments outline in this paper is not the same of that reported by Jobbágy et al., (2014, 2015), which included 71 registered European participant laboratories in the ILC. Despite its importance, such type of initiative involves costs, demanding time and several arrangements to its implementation, but the present conditions existing in South America don't allow similar evaluation as only a few laboratories are able to perform these analyses in waters. Additionally, there is a large data scarcity for these parameters in Brazilian waters, justifying the use of faster and cheaper analytical methods like that suggested in this paper.

\section{Theoretical approach}

Natural radioactivity is basically generated by the decay of cosmogenic radionuclides $\left({ }^{14} \mathrm{C},{ }^{26} \mathrm{Al},{ }^{10} \mathrm{Be},{ }^{3} \mathrm{H}\right.$, and $\left.{ }^{36} \mathrm{Cl}\right)$ and radionuclides associated directly with the geological environment (e.g. ${ }^{238} \mathrm{U}$, ${ }^{235} \mathrm{U},{ }^{232} \mathrm{Th}$ and ${ }^{40} \mathrm{~K}$ ) (Bentley et al., 1986; Faure and Mensing, 2005). ${ }^{238} \mathrm{U},{ }^{235} \mathrm{U}$, and ${ }^{232} \mathrm{Th}$ originate decay series with a significant number of daughters and having $\mathrm{Pb}$ isotopes as stable end-members. $\mathrm{U}$, Th and $\mathrm{K}$ are present in the lithosphere since the Earth's formation and are still one of the major contributors to the environmental radioactivity and radiological characterization of the waters.

${ }^{238} \mathrm{U}$ is the most abundant uranium isotope (99.3\%). Its decay chain has 15 daughters, finishing at stable ${ }^{206} \mathrm{~Pb}$ (Chu et al., 1999). ${ }^{235} \mathrm{U}$ has a lower $(0.7 \%)$ abundance and a simpler decay chain finishing at stable ${ }^{207} \mathrm{~Pb}$ (Chu et al., 1999). ${ }^{232} \mathrm{Th}$ practically represents the totality $(99.98 \%)$ of thorium in nature and its series finishes at stable ${ }^{208} \mathrm{~Pb}$ (Chu et al., 1999). The radioactivity related to potassium is entirely based on the ${ }^{40} \mathrm{~K}$ (abundance $=0.012 \%$ ) disintegration. It decays to ${ }^{40} \mathrm{Ca}$ through a $\beta^{-}$emission $(89.3 \%)$ and to ${ }^{40} \mathrm{Ar}$ by electron capture $(10.7 \%)$, in this case also occurring a $1460.83 \mathrm{keV}$ energy gamma emission (Chu et al., 1999).

The ${ }^{235} \mathrm{U}$ and associated daughters contribution to the radiological quality of most waters is often neglected due to its low isotopic abundance relative to the one of ${ }^{238} \mathrm{U}$. But its shorter half-life implies on a higher specific activity value. In terms of solubility, uranium is of easy incorporation into waters when compared to thorium, even though solubility might be a very complex issue if $\mathrm{pH}$, Eh, colloidal particles and concentration of other ions in water are considered. Despite the fact that uranium is more soluble, the concentration of thorium in crustal rocks, however, is approximately three to four times higher (Rogers and Adams, 1969a, 1969b; Thorton, 1983; Clark, 1989).

The technique adopted here uses a gamma spectrometric system for the characterization of gross alpha and beta activities in an indirect way. Gamma rays associated with these particles emissions in the ${ }^{238} \mathrm{U}$, ${ }^{232} \mathrm{Th}$, and ${ }^{235} \mathrm{U}$ decay series are shown in Tables 1,2 . Regarding to $\alpha$ decays, the most notable characteristic is the absence of peaks associated with intense and isolated gamma emissions as there are overlapped signals that make the calibration more difficult. In this case, the most viable representatives of ${ }^{238} \mathrm{U}$ and ${ }^{232} \mathrm{Th}$ series are ${ }^{226} \mathrm{Ra}$ $(186.21 \mathrm{keV})$ and ${ }^{224} \mathrm{Ra}(240.99 \mathrm{keV})$, respectively. On the other hand, there are several options for choosing gamma emissions related to $\beta$ decays, for instance: ${ }^{238} \mathrm{U}$ series - ${ }^{214} \mathrm{Bi}$ (609.31, 1120.29, and $1764.49 \mathrm{keV}) ;{ }^{232} \mathrm{Th}$ series $-{ }^{208} \mathrm{Tl}$ (583.19 and $\left.2614.53 \mathrm{keV}\right),{ }^{228} \mathrm{Ac}$ (911.20 and $968.97 \mathrm{keV}),{ }^{212} \mathrm{~Pb}(238.63 \mathrm{keV})$.

\subsection{Calibration steps}

The $\gamma$-rays detector utilized in association with the spectrometric system was a coaxial EG\&G ORTEC HPGe type whose resolution is $2.1 \mathrm{keV}$ and efficiency $63 \%$ at the $1332.50 \mathrm{keV}{ }^{60} \mathrm{Co}$ peak. The X-Cooler III unit provided a $77 \mathrm{~K}$ temperature for the system, which also utilizes an EG\&G ORTEC ASPEC-927 multichannel buffer and Gamma Vision software for the data acquisition.

The calibration in energy was performed using the artificial radioactive sources ${ }^{133} \mathrm{Ba}(356.02 \mathrm{keV}),{ }^{137} \mathrm{Cs}(661.66 \mathrm{keV})$ and ${ }^{60} \mathrm{Co}$ (1173.24, 1332.50 and $2505.74 \mathrm{keV}$ - "sum peak"), as well the following $\gamma$-rays emissions from a $1 \%$ uranium standard: ${ }^{210} \mathrm{~Pb}-46.54 \mathrm{keV}$ (4.2\%), ${ }^{226} \mathrm{Ra}-186.21 \mathrm{keV}(3.6 \%),{ }^{214} \mathrm{~Pb}-295.22$ (19.3\%) and $351.93 \mathrm{keV}(37.6 \%)$, and ${ }^{214} \mathrm{Bi}-609.31 \mathrm{keV}(46.1 \%)$. Two graphs of energy (keV) vs. channel were generated (Fig. 1): $E=0.2009$. Ch +4.4577 (lower energy interval of $40-600 \mathrm{keV}$ ) and $E=0.2003$. Ch +4.8454 (higher energy interval of $600-2600 \mathrm{keV}$ ), where $E$ is the energy (keV) and $C h$ is the channel number in the multichannel analyzer.

The system calibration in activity concentration used radioactive sources containing uranium, thorium and potassium. New Brunswick Laboratory of U.S. Department of Energy, Argonne, Illinois, provided the $\mathrm{U}$ and Th sources, whereas mixture of $\mathrm{KCl}$ and silica supplied the ${ }^{40} \mathrm{~K}$ sources. Table 3 shows the main characteristics of the standards 
Table 1

Gamma emissions related to $\beta$-emitting radionuclides belonging to ${ }^{238} \mathrm{U},{ }^{235} \mathrm{U}$ and ${ }^{232} \mathrm{Th}$ decay series with their respective absolute intensity (only values higher than $1 \%$ are listed). According to Chu et al. (1999).

\begin{tabular}{|c|c|c|c|}
\hline Decay series & Radionuclide & Energy (keV) & Absolute intensity (\%) \\
\hline \multirow[t]{29}{*}{${ }^{238} \mathrm{U}$} & \multirow[t]{3}{*}{${ }^{234} \mathrm{Th}$} & 63.29 & 4.8 \\
\hline & & 92.38 & 2.8 \\
\hline & & 92.80 & 2.8 \\
\hline & \multirow[t]{5}{*}{${ }^{214} \mathrm{~Pb}$} & 53.23 & 1.2 \\
\hline & & 242.00 & 7.4 \\
\hline & & 295.22 & 19.3 \\
\hline & & 351.93 & 37.6 \\
\hline & & 785.96 & 1.1 \\
\hline & \multirow[t]{20}{*}{${ }^{214} \mathrm{Bi}$} & 609.31 & 46.1 \\
\hline & & 665.45 & 1.5 \\
\hline & & 768.35 & 4.9 \\
\hline & & 806.17 & 1.2 \\
\hline & & 934.06 & 3.0 \\
\hline & & 1120.29 & 15.1 \\
\hline & & 1155.19 & 1.6 \\
\hline & & 1238.11 & 3.8 \\
\hline & & 1280.96 & 1.4 \\
\hline & & 1377.67 & 4.0 \\
\hline & & 1401.50 & 1.3 \\
\hline & & 1407.98 & 2.2 \\
\hline & & 1509.23 & 2.1 \\
\hline & & 1661.28 & 1.2 \\
\hline & & 1729.60 & 2.9 \\
\hline & & 1764.49 & 15.4 \\
\hline & & 1847.42 & 2.1 \\
\hline & & 2118.55 & 1.1 \\
\hline & & 2204.21 & 5.1 \\
\hline & & 2447.86 & 1.6 \\
\hline & ${ }^{210} \mathrm{~Pb}$ & 46.54 & 4.2 \\
\hline \multirow[t]{29}{*}{${ }^{232} \mathrm{Th}$} & ${ }^{228} \mathrm{Ra}$ & 13.52 & 1.6 \\
\hline & \multirow[t]{16}{*}{${ }^{228} \mathrm{Ac}$} & 99.51 & 1.3 \\
\hline & & 129.07 & 2.4 \\
\hline & & 209.25 & 3.9 \\
\hline & & 270.25 & 3.5 \\
\hline & & 328.00 & 3.0 \\
\hline & & 338.32 & 1,3 \\
\hline & & 409.46 & 1.9 \\
\hline & & 463.00 & 4.4 \\
\hline & & 772.29 & 1.5 \\
\hline & & 794.95 & 4.2 \\
\hline & & 835.71 & 1.6 \\
\hline & & 911.20 & 25.8 \\
\hline & & 964.77 & 5.0 \\
\hline & & 968.97 & 15.8 \\
\hline & & 1588.19 & 3.2 \\
\hline & & 1630.63 & 1.5 \\
\hline & \multirow[t]{2}{*}{${ }^{212} \mathrm{~Pb}$} & 238.63 & 43.3 \\
\hline & & 300.09 & 3.3 \\
\hline & \multirow[t]{4}{*}{${ }^{212} \mathrm{Bi}$} & 39.86 & 1.1 \\
\hline & & 727.33 & 6.6 \\
\hline & & 785.37 & 1.1 \\
\hline & & 1620.50 & 1,5 \\
\hline & \multirow[t]{6}{*}{${ }^{208} \mathrm{Tl}$} & 277.35 & 6.3 \\
\hline & & 510.77 & 22.6 \\
\hline & & 583.19 & 84.5 \\
\hline & & 763.13 & 1.8 \\
\hline & & 860.56 & 12.4 \\
\hline & & 2614.53 & 99.0 \\
\hline \multirow[t]{5}{*}{${ }^{235} \mathrm{U}$} & \multirow[t]{2}{*}{${ }^{231} \mathrm{Th}$} & 25.64 & 14.5 \\
\hline & & 84.22 & 6.6 \\
\hline & \multirow[t]{3}{*}{${ }^{211} \mathrm{~Pb}$} & 404.85 & 3.8 \\
\hline & & 427.09 & 1.8 \\
\hline & & 832.01 & 3.5 \\
\hline
\end{tabular}

utilized, whilst Fig. 2 illustrates some of the acquired gamma spectra. Total alpha/beta measurements for these reference materials are not available. However, a scintillator crystal of $\mathrm{Bi}_{4} \mathrm{Ge}_{3} \mathrm{O}_{12}$ (BGO-bismuth germanate; $7.13 \mathrm{~g} / \mathrm{cm}^{3}$ density) provided dose rate readings as shown in Table 3. The dose rate values increase according to the concentration raising of the certified values, adjusting to a straight line that exhibits a
Table 2

Gamma emissions related to $\alpha$-emitting radionuclides belonging to ${ }^{238} \mathrm{U},{ }^{235} \mathrm{U}$ and ${ }^{232} \mathrm{Th}$ decay series with their respective absolute intensity (only values higher than $1 \%$ are listed). According to Chu et al. (1999).

\begin{tabular}{|c|c|c|c|}
\hline Decay series & Radionuclide & Energy (keV) & Absolute intensity (\%) \\
\hline${ }^{238} \mathrm{U}$ & ${ }^{226} \mathrm{Ra}$ & 186.21 & 3.6 \\
\hline \multirow[t]{3}{*}{${ }^{232} \mathrm{Th}$} & ${ }^{228} \mathrm{Th}$ & 84.37 & 1.2 \\
\hline & ${ }^{224} \mathrm{Ra}$ & 240.99 & 4.1 \\
\hline & ${ }^{212} \mathrm{Bi}$ & 39.86 & 1.1 \\
\hline \multirow[t]{30}{*}{${ }^{235} \mathrm{U}$} & ${ }^{235} \mathrm{U}$ & 109.16 & 1.5 \\
\hline & & 163.36 & 5.1 \\
\hline & & 185.71 & 57.2 \\
\hline & & 202.11 & 1.1 \\
\hline & & 205.30 & 5.0 \\
\hline & ${ }^{231} \mathrm{~Pa}$ & 27.36 & 10.3 \\
\hline & & 283.69 & 1.7 \\
\hline & & 300.07 & 2.5 \\
\hline & & 302.65 & 2.2 \\
\hline & & 330.06 & 1.4 \\
\hline & ${ }^{227} \mathrm{Th}$ & 50.13 & 8.0 \\
\hline & & 79.72 & 1.9 \\
\hline & & 93.93 & 1.4 \\
\hline & & 210.65 & 1.1 \\
\hline & & 235.97 & 12.3 \\
\hline & & 256.25 & 7.0 \\
\hline & & 286.12 & 1.5 \\
\hline & & 300.00 & 2.3 \\
\hline & & 304.52 & 1.2 \\
\hline & & 329.85 & 2.7 \\
\hline & ${ }^{223} \mathrm{Ra}$ & 122.32 & 1.2 \\
\hline & & 144.23 & 3.2 \\
\hline & & 154.21 & 5.6 \\
\hline & & 269.46 & 13.7 \\
\hline & & 323.87 & 3.9 \\
\hline & & 338.28 & 2.8 \\
\hline & & 445.03 & 1.3 \\
\hline & ${ }^{219} \mathrm{Rn}$ & 271.23 & 10.8 \\
\hline & & 401.81 & 6.4 \\
\hline & ${ }^{211} \mathrm{Bi}$ & 351.06 & 12.9 \\
\hline
\end{tabular}
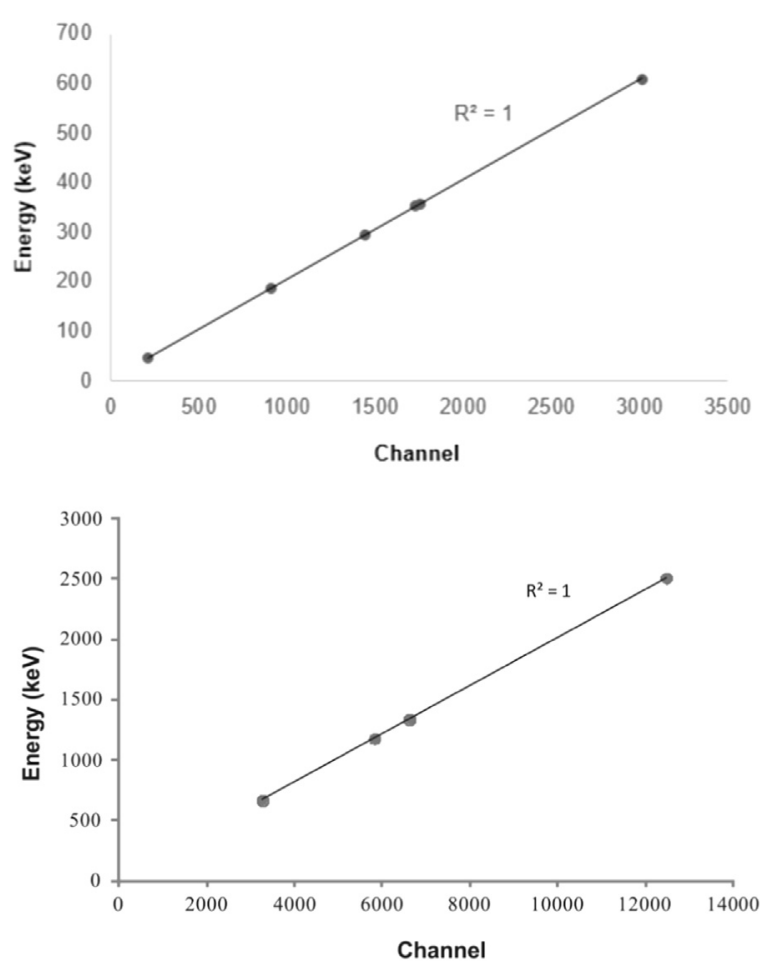

Fig. 1. Calibration curves in energy of the $\gamma$-rays spectrometric system for the (top) lower energy interval of 40-600 keV and (bottom) higher energy interval of 600-2600 keV. 
Table 3

Standards used for calibrating the HPGe $\gamma$-rays spectrometer used in this study.

\begin{tabular}{|c|c|c|c|c|c|}
\hline Standard & Code & Composition & Weight (g) & Concentration $^{\mathrm{a}}$ & 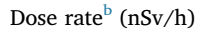 \\
\hline K1 & LII-KCL-1 & $61.5 \mathrm{~g} \mathrm{KCl}$ & 61.50 & $52 \pm 0.52 \mathrm{wt} \% \mathrm{~K}$ & 102.7 \\
\hline K2 & LII-KCL-2 & $54.16 \mathrm{~g} \mathrm{SiO}_{2}+28.9 \mathrm{~g} \mathrm{KCl}$ & 83.06 & $25 \pm 0.25 \mathrm{wt} \% \mathrm{~K}$ & 76.1 \\
\hline K3 & LII-KCL-3 & $80.12 \mathrm{~g} \mathrm{SiO}_{2}+5.80 \mathrm{~g} \mathrm{KCl}$ & 85.92 & $5 \pm 0.05 w t \% \mathrm{~K}$ & 78.9 \\
\hline K4 & LII-KCL-4 & $82.11 \mathrm{~g} \mathrm{SiO}_{2}+2.90 \mathrm{~g} \mathrm{KCl}$ & 85.01 & $2.5 \pm 0.025 w t \% \mathrm{~K}$ & 78.6 \\
\hline K5 & LII-KCL-5 & $84.72 \mathrm{~g} \mathrm{SiO}_{2}+0.5 \mathrm{~g} \mathrm{KCl}$ & 85.22 & $0.5 \pm 0.005 w t \% \mathrm{~K}$ & 85.4 \\
\hline $\mathrm{U} 1$ & CRM 101-A & Pitchblende ore - sílica mixture & 50 & $1.007 \pm 0.013 w \mathrm{t} \% \mathrm{U}$ & 879.2 \\
\hline $\mathrm{U} 2$ & CRM 102-A & Pitchblende ore - sílica mixture & 50 & $0.1025 \pm 0.0019 w t \% \mathrm{U}$ & 150.9 \\
\hline U3 & CRM 103-A & Pitchblende ore - sílica mixture & 50 & $0.0499 \pm 0.0007 w \mathrm{t} \% \mathrm{U}$ & 166.4 \\
\hline $\mathrm{U} 4$ & CRM 104-A & Pitchblende ore - sílica mixture & 50 & $0.00988 \pm 0.0002 \mathrm{wt} \% \mathrm{U}$ & 127.3 \\
\hline U5 & CRM 105-A & Pitchblende ore - sílica mixture & 50 & $0.00102 \pm 0.00002 \mathrm{wt} \% \mathrm{U}$ & 128.4 \\
\hline Th1 & CRM 106-A & Monazite sand - sílica mixture & 50 & $1.029 \pm 0.003 \mathrm{wt} \% \mathrm{Th}$ & 423.0 \\
\hline Th2 & CRM 107-A & Monazite sand - sílica mixture & 50 & $0.1028 \pm 0.0002 w t \% \mathrm{Th}$ & 107.9 \\
\hline Th3 & CRM 108-A & Monazite sand - sílica mixture & 50 & $0.0515 \pm 0.0002 \mathrm{wt} \% \mathrm{Th}$ & 87.5 \\
\hline Th4 & CRM 109-A & Monazite sand - sílica mixture & 50 & $0.01052 \pm 0.00009 \mathrm{wt} \% \mathrm{Th}$ & 76.8 \\
\hline Th5 & CRM 110-A & Monazite sand - sílica mixture & 50 & $0.00104 \pm 0.00001 \mathrm{wt} \% \mathrm{Th}$ & 75.3 \\
\hline
\end{tabular}

a Reported by NBL (1999) for standards U1-U5 and Th1-Th5.

${ }^{\mathrm{b}}$ Reported by Barbosa (2016) for scintillations counting during $1800 \mathrm{~s}$ as performed with a BGO-bismuth germanate portable gamma rays spectrometer.

strong significant Pearson correlation coefficient $(r=0.98)$.

Gamma rays peaks representing $\beta^{-}$and $\alpha$ disintegrations from ${ }^{238} \mathrm{U}$ and ${ }^{232} \mathrm{Th}$ decay series were selected for calibration purposes. The criteria adopted were the intensities of the gamma emissions, absence of interference from other $\gamma$-rays energies in the peak (overlap) and enough energy difference between two close peaks. The selected $\gamma$-rays energies were: ${ }^{238} \mathrm{U}$ series - ${ }^{226} \mathrm{Ra}(\alpha$-decay, $186.21 \mathrm{keV})$ and ${ }^{214} \mathrm{Bi}\left(\beta^{-}\right.$decay, 1120.29 and $1764.49 \mathrm{keV}) ;{ }^{232} \mathrm{Th}$ series - ${ }^{224} \mathrm{Ra}$ ( $\alpha$-decay, $240.99 \mathrm{keV}),{ }^{208} \mathrm{Tl}$ ( $\beta^{-}$-decay, 583.19 and $\left.2614.53 \mathrm{keV}\right)$ and ${ }^{228} \mathrm{Ac}\left(\beta^{-}\right.$decay, 911.20 and $968.97 \mathrm{keV}$ ). ${ }^{40} \mathrm{~K}$ data were acquired from $\gamma$-rays of $1460.83 \mathrm{keV}$ energy.

However, ${ }^{226} \mathrm{Ra}$ peak overlaps ${ }^{235} \mathrm{U}(185.71 \mathrm{keV})$ in the gamma spectrum. Its contribution in each peak corresponded to $5.9 \%$ of the total counting rate as estimated from both absolute intensities and specific activities. The ${ }^{235} \mathrm{U}$ contribution was not considered in the gross alpha evaluation in this paper, but, if necessary, it could be easily included. ${ }^{224} \mathrm{Ra}(240.99 \mathrm{keV})$ suffers a more complex interference that involves three disintegrations: ${ }^{212} \mathrm{~Pb}-238.63 \mathrm{keV}\left({ }^{232} \mathrm{Th}\right.$ series); ${ }^{227} \mathrm{Th}$ $235.97 \mathrm{keV}\left({ }^{235} \mathrm{U}\right.$ series $) ;{ }^{214} \mathrm{~Pb}-242 \mathrm{keV}\left({ }^{238} \mathrm{U}\right.$ series $)$. In this case, the ${ }^{224} \mathrm{Ra}$ contribution in the peak corresponds to $0.03 \%$ of the total counting rate.

The activity concentration of each radioactive source was calculated from the concentration values (in ppm for $\mathrm{U}$ and $\mathrm{Th}$ and in \% for $\mathrm{K}$ ), adopting the following specific activity values: ${ }^{238} \mathrm{U}-12,437 \mathrm{~Bq} \mathrm{~g}^{-1}$; ${ }^{232} \mathrm{Th}-4057 \mathrm{~Bq} \mathrm{~g}^{-1}$; $\mathrm{K}-31.3 \mathrm{~Bq} \mathrm{~g}^{-1}$ (Pearce, 2008). The effective intensity (counting rate by mass, cps. ${ }^{-1}$ ) was determined in each standard for all radionuclides of interest. Table 4 shows logarithmic equations for the activity concentration of $\mathrm{U}$, Th and $\mathrm{K}$ in function of the effective intensity. Two reference materials from New Brunswick Laboratory possessing $\mathrm{U}$ concentrations of $40 \mathrm{\mu g} \mathrm{g}^{-1}$ (CRM 107-A) and $400 \mathrm{\mu g} \mathrm{g}^{-1}$ (CRM 106-A) were subjected to the $\gamma$-rays analysis, allowing verify that the use of eqs. in Table 3 yielded results deviating up to $5 \%$ of the certified values, thus, evidencing absence of systematic errors (measurement bias).

The detection efficiency $(\mathcal{E} f)$ is the ratio of the number of detected events $\left(d_{1}\right)$ to the real number of decays $\left(d_{0}\right)$ from the radioactive source, i.e. $\mathcal{E} f(\%)=d_{1} / d_{o}$ (Rodrigues et al., 2011). It may be also determined by the equation $\varepsilon f(\%)=\left(T_{S}-T_{B}\right) /\left(f\right.$. $\left.A_{S}\right)$ where: $T_{S}$ is the counting rate (in cps) in the selected peak of the standard, $T_{B}$ is the background counting rate (in cps), $f$ (in \%) is the absolute intensity of the $\gamma$-rays peak and $A_{S}$ (in $\mathrm{Bq}$ ) is the standard activity. The detection efficiency according to the $\gamma$-rays energy has been determined for the following radionuclides: ${ }^{210} \mathrm{~Pb}(46.54 \mathrm{keV}),{ }^{214} \mathrm{~Pb}(242.00,295.22$ and $351.93 \mathrm{keV}),{ }^{214} \mathrm{Bi}(609.31,1120.29,1764.49$ and $2204.21 \mathrm{keV}),{ }^{208} \mathrm{Tl}$ (583.19 and $2614.53 \mathrm{keV}$ ), ${ }^{228} \mathrm{Ac}\left(911.20\right.$ and $968.97 \mathrm{keV}$ ) and ${ }^{40} \mathrm{~K}$
( $1460.83 \mathrm{keV})$. A detection efficiency curve was obtained with a fourth degree polynomial comprising lower gamma energies in the range of 46-968 keV and a quadratic function for higher values (up to $2614 \mathrm{keV}$ ) (Fig. 3). The detection efficiency tends to decrease according to the increase of the $\gamma$-rays energy.

\section{Experimental}

Groundwater samples were analyzed for gross alpha and beta activities using the two described approaches. The first was based on the equations given in Table 4, whereas the second from the equation $A_{s a}$ $=\left(T_{s a}-T_{B}\right) /(f . \mathcal{E} f)$ where: $A_{s a}$ is the sample activity (in Bq), $T_{s a}$ is the counting rate (in cps) in the selected peak of the sample and $T_{B}$ is the background counting rate there (in cps). In total, 108 groundwater samples from 33 municipalities comprising different geologic contexts and aquifer systems in the Brazilian states of São Paulo, Minas Gerais and Mato Grosso do Sul were analyzed (Fig. 4 and Table 5). They were collected from wells and public pipes and springs of easy access and often used by the local population and tourists, mainly in the localities classified as spa towns where people seek health treatment based on waters with specific chemical composition. After sampling, the waters were stored in properly sealed and identified polyethylene containers.

The dominant geologic contexts are the Phanerozoic sedimentary rocks from Paraná Basin (mainly related to porous aquifer systems) and the crystalline terrains (associated with fractured aquifers). The first group of samples is chiefly located in the states of São Paulo and Mato Grosso do Sul (Fig. 4). Some tube wells are $\sim 3000 \mathrm{~m}$ deep, comprising almost the entire stratigraphic sequence in São Paulo State, except for the basal sandstones of Furnas Formation (Early Devonian). The other superimposed units are: Itararé Subgroup (Late Carboniferous to Early Permian) - diamictites and sandstones (Milani et al., 2007); Tatuí Formation (Early Permian) - siltstones and sandstones (Soares, 1972), which, along with Itararé Subgroup, comprises the Tubarão Aquifer System; Passa Dois Group (Irati and Corumbataí formations, Late Permian in age) - fine grained sedimentary rocks, such as shales, mudstones, siltstones, and layers of dolomites, often considered an aquiclude due to the low permeability lithotypes (Iritani and Ezaki, 2012); Pirambóia and Botucatu formations - Mesozoic sandstones (Schneider et al., 1974), forming the Guarani Aquifer System (GAS), one of the largest aquifer units of the world; Serra Geral Formation (Late Jurassic to Early Cretaceous) - basalt flows and dikes generated by the breakup of Gondwana Supercontinent during Mesozoic Era (Milani et al., 2007), representing the unique fractured aquifer unit in Paraná Basin; Bauru Group (Late Cretaceous) - lithologically heterogeneous sandstones, siltstones, mudstones and locally conglomerates and limestones 

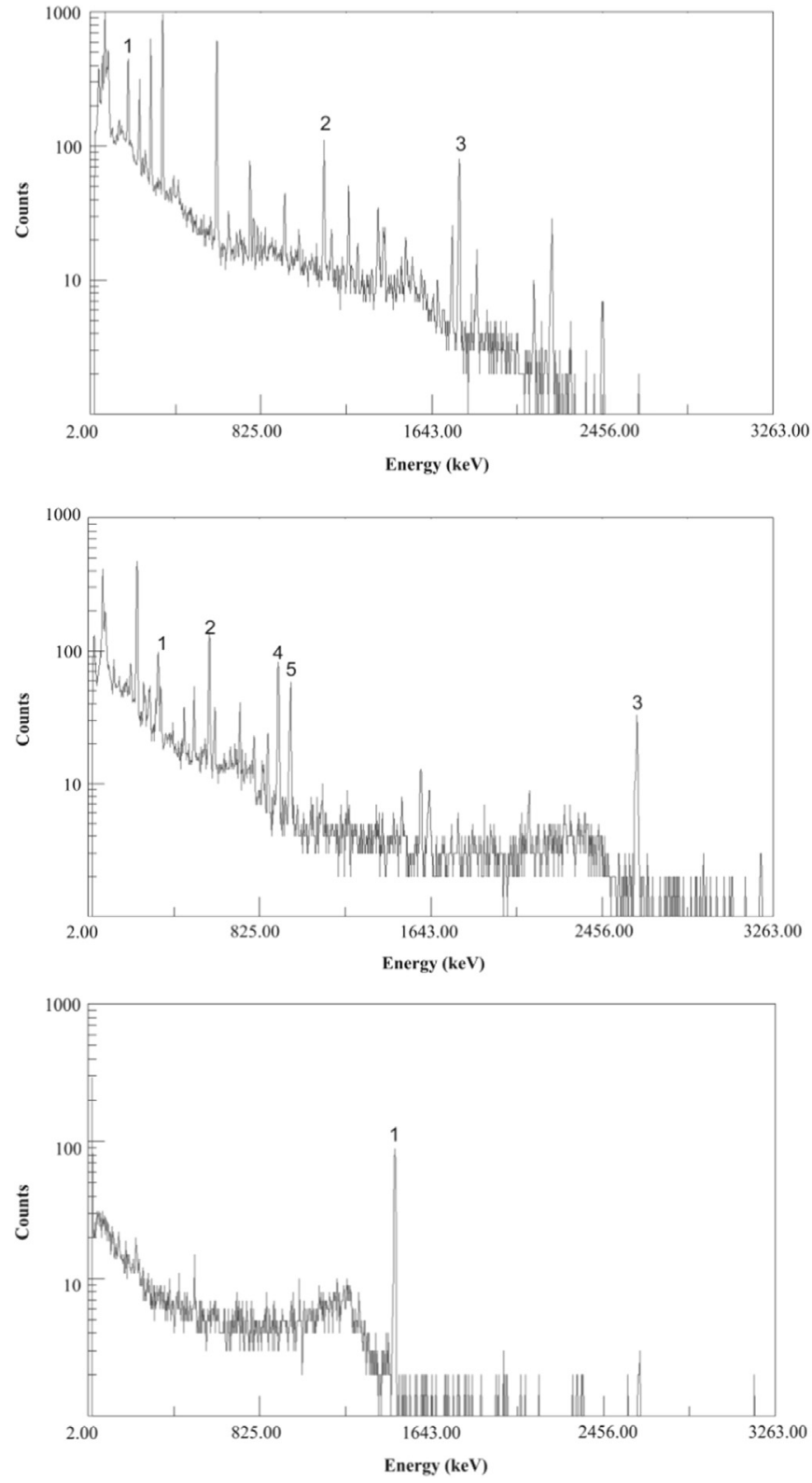

Fig. 2. (top) $\gamma$-rays spectrum for uranium standard ( $1 \% \mathrm{U})$ : peak $1\left({ }^{226} \mathrm{Ra}-186.21 \mathrm{keV}\right)$, peaks 2 and $3\left({ }^{214} \mathrm{Bi}-1120.29\right.$ and $1764.49 \mathrm{keV}$, respectively); (middle) $\gamma$-rays spectrum for thorium standard (1\% Th): peak $1\left({ }^{224} \mathrm{Ra}-240.99 \mathrm{keV}\right)$, peaks 2 and $3\left({ }^{208} \mathrm{Tl}-583.19\right.$ and $2614.53 \mathrm{keV}$, respectively), peaks 4 and $5\left({ }^{228} \mathrm{Ac}-911.20\right.$ and $968.97 \mathrm{keV}$, respectively); (bottom) $\gamma$-rays spectrum for potassium standard $(52 \% \mathrm{~K})$ : peak $1\left({ }^{40} \mathrm{~K}\right.$ $1460.83 \mathrm{keV})$.

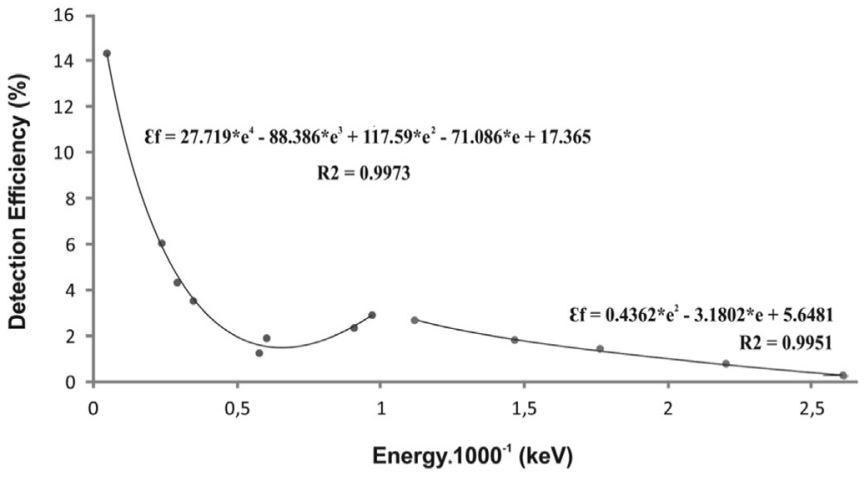

Fig. 3. Efficiency detection curves generated for the spectrometric system and their respective correlation coefficients. Ef corresponds to the efficiency (in \%) and e is the $\gamma$-rays energy (in keV) divided by 1000 .

(Fernandes, 2004), comprising the top unit of the sedimentary sequence.

In terms of fractured aquifer units, samples from Águas da Prata, Poços de Caldas and Pocinhos do Rio Verde municipalities can be grouped in the context of the Poços de Caldas Alkaline Massif (PCAM). The local geology can be defined as an alkaline intrusion into gneissicgranitic terrains during the Cretaceous Period. Thedeschi et al. (2015) describe it as a predominance of tinguaites and phonolites, with subordinated nepheline syenites, lujaurites and piroclastic rocks. On the edge of the massif, near to Águas da Prata city, some of the springs are associated with diabase dikes (Serra Geral Formation) and silicified sandstones with similar structures observed in Botucatu Formation (Szikszay and Teissedre, 1977).

Additionally, groundwater samples were taken from Alto do Rio Grande Strip, a Meso-proterozoic tectonic unit marginal to São Francisco Craton with Anchean to Paleo-proterozoic fragments affected by Brasiliano Orogeny (Hasui and Oliveira, 1984; Campos Neto, 1991). The lithotypes can be resumed by Archean gneissic-migmatite predominant basement (Amparo Complex and equivalent units) covered by allochthonous Mesoproterozoic metavolcanic and metasedimentary sequences defined by Andrelândia/São João del Rey/Itapira Group, which consists of micaceous and pure quartzites, garnet schists, metagraywackes, anfibolites, etc. (Campos Neto et al., 1990). Beato et al. (1999) describes the presence of alkaline veins with hydrothermal alteration in the area of the water springs of Caxambu, which might be related to the syenite intrusive body identified in the region (Trouw et al., 2003).

Marinelli-type beaker with $1 \mathrm{~L}$ capacity was used for the $\gamma$-rays analysis of the groundwater samples, which lasted about $8.5 \mathrm{~h}$ each. The gross beta activity was calculated by the sum of the activity concentrations regarding to ${ }^{40} \mathrm{~K}$ and selected radionuclides from ${ }^{238} \mathrm{U}$ $\left({ }^{214} \mathrm{Bi}, 1120.29 \mathrm{keV}\right)$ and ${ }^{232} \mathrm{Th}\left({ }^{208} \mathrm{Tl}, 583.19 \mathrm{keV}\right)$ decay series. The gross alpha activity was calculated by the sum of the activity concentrations related to ${ }^{226} \mathrm{Ra}\left({ }^{238} \mathrm{U}\right.$ series) and ${ }^{224} \mathrm{Ra}\left({ }^{232} \mathrm{Th}\right.$ series). The statistical uncertainty in the gamma readings was $\pm 5-10 \%$ in each

Table 4

Equations relating the activity concentration of each radionuclide of interest $\left(A_{i}\right.$, in Bq. $\left.g^{-1}\right)$ with their respective effective intensity (Ie, in cps.g $\left.{ }^{-1}\right)$

\begin{tabular}{|c|c|c|c|c|}
\hline Radionuclide (energy) & Decay mode & Decay series & Equation & $\mathrm{r}^{2}$ \\
\hline${ }^{214} \mathrm{Bi}(1120.29 \mathrm{keV})$ & $\beta^{-}$ & ${ }^{238} \mathrm{U}$ & $\log \left(\mathrm{A}_{U}\right)=1.0409 \times \log (\mathrm{Ie})+2.7229$ & 0.9994 \\
\hline${ }^{214} \mathrm{Bi}(1764.49 \mathrm{keV})$ & $\beta$ & ${ }^{238} \mathrm{U}$ & $\log \left(\mathrm{A}_{\mathrm{U}}\right)=1.0284 \times \log (\mathrm{Ie})+2.8427$ & 0.9989 \\
\hline${ }^{226} \mathrm{Ra}(186.21 \mathrm{keV})$ & $\alpha$ & ${ }^{238} \mathrm{U}$ & $\log \left(\mathrm{A}_{\mathrm{U}}\right)=1.0117 \times \log (\mathrm{Ie})+3.4256$ & 0.9975 \\
\hline${ }^{228} \mathrm{Ac}(911.20 \mathrm{keV})$ & $\beta^{-}$ & ${ }^{232} \mathrm{Th}$ & $\log \left(\mathrm{A}_{\mathrm{Th}}\right)=0.9998 \times \log (\mathrm{Ie})+2.2109$ & 0.9999 \\
\hline${ }^{228} \mathrm{Ac}(968.97 \mathrm{keV})$ & $\beta^{-}$ & ${ }^{232} \mathrm{Th}$ & $\log \left(\mathrm{A}_{\mathrm{Th}}\right)=0.9977 \times \log (\mathrm{Ie})+2.3261$ & 0.9999 \\
\hline${ }^{208} \mathrm{Tl}(583.19 \mathrm{keV})$ & $\beta^{-}$ & ${ }^{232} \mathrm{Th}$ & $\log \left(\mathrm{A}_{\mathrm{Th}}\right)=0.9966 \times \log (\mathrm{Ie})+1.9734$ & 0.9999 \\
\hline${ }^{208} \mathrm{Tl}(2614.53 \mathrm{keV})$ & $\beta$ & ${ }^{232} \mathrm{Th}$ & $\log \left(\mathrm{A}_{\mathrm{Th}}\right)=0.9989 \times \log (\mathrm{Ie})+2.5471$ & 0.9998 \\
\hline${ }^{224} \mathrm{Ra}(240.99 \mathrm{keV})$ & $\alpha$ & ${ }^{232} \mathrm{Th}$ & $\log \left(\mathrm{A}_{\mathrm{Th}}\right)=1.0569 \times \log (\mathrm{Ie})+3.1067$ & 0.9968 \\
\hline${ }^{40} \mathrm{~K}(1460.83 \mathrm{keV})$ & e.c. & - & $\log \left(\mathrm{A}_{\mathrm{K}}\right)=1.2133 \times \log (\mathrm{Ie})+3.1941$ & 0.9895 \\
\hline
\end{tabular}




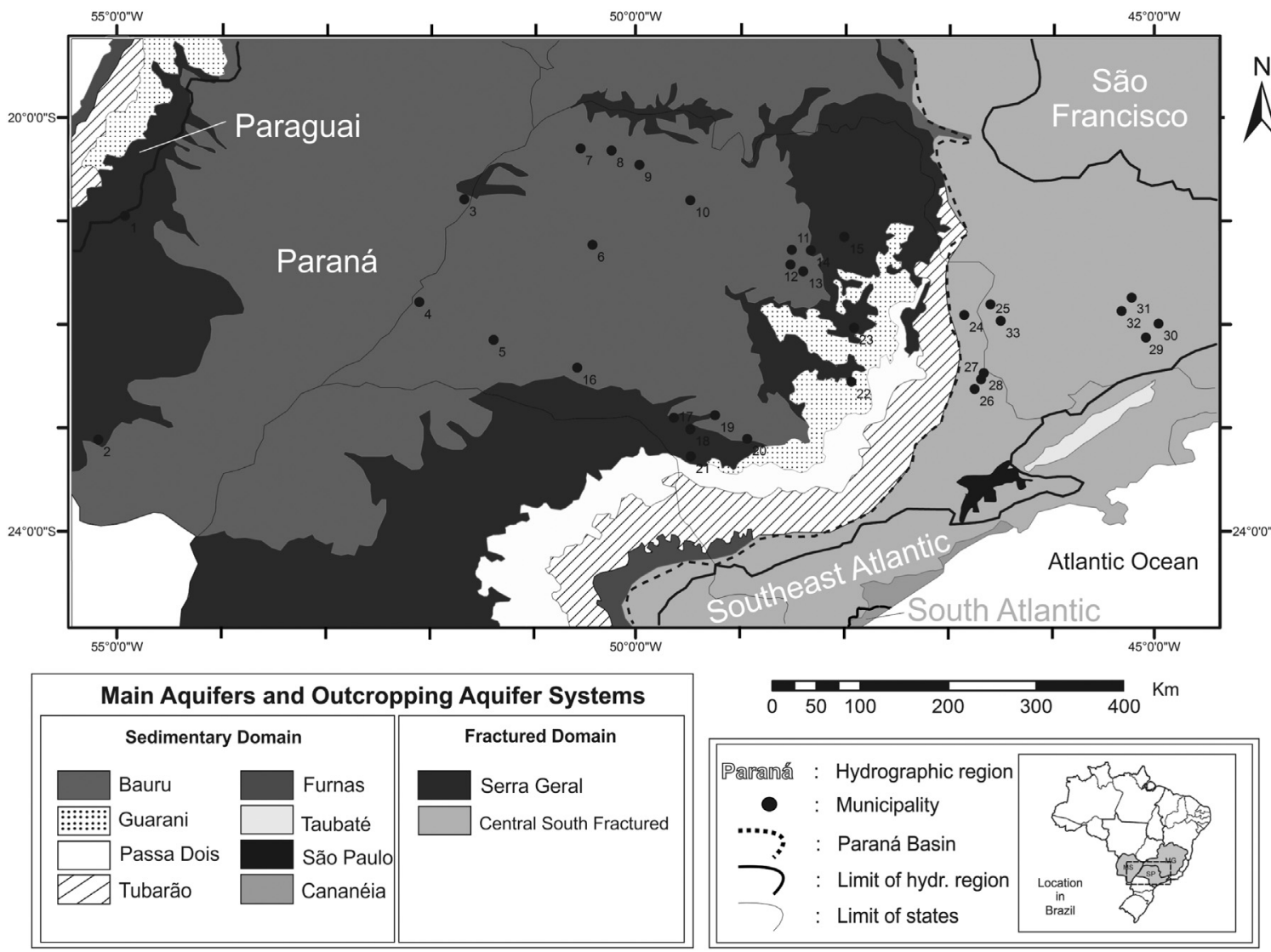

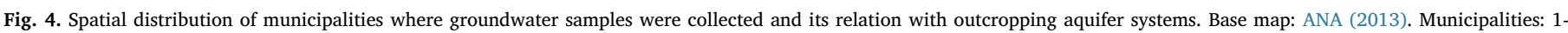

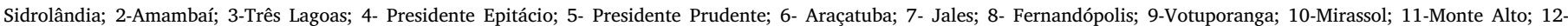

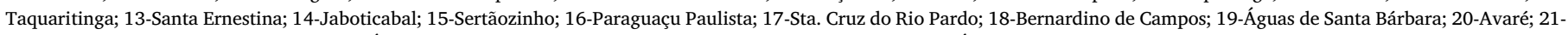

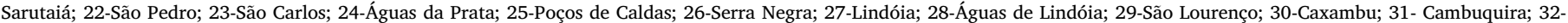
Lambari; 33- Pocinhos do Rio Verde.

peak, within $1 \sigma$ standard deviation. The count rate in some samples was low during the gamma spectrometric readings. To determine whether the observed signal was "true" or "false", it was adopted the critical level of detection $(L c)$, expressed in number of counts as $L c=2.33(B)^{1 / 2}$ (Currie, 1968), where $B$ is the number of background counts. The data on the background gamma spectra across the $186-1461 \mathrm{keV}$ energy region allowed the estimate of $L c$ in activity concentration of 0.010 , $0.023,0.038,0.086$, and $0.042 \mathrm{~Bq} / \mathrm{L}$, respectively, for ${ }^{226} \mathrm{Ra}$ $(186.21 \mathrm{keV}), \quad{ }^{224} \mathrm{Ra} \quad(240.99 \mathrm{keV}), \quad{ }^{208} \mathrm{Tl} \quad(583.19 \mathrm{keV}), \quad{ }^{214} \mathrm{Bi}$ $(1120.29 \mathrm{keV})$ and ${ }^{40} \mathrm{~K}(1460.83 \mathrm{keV})$. Therefore, such $L c$ values are much lower than the WHO (2011) guideline reference values for gross alpha and beta in waters, respectively, 0.5 and $1.0 \mathrm{~Bq} / \mathrm{L}$.

\section{Results and discussion}

Table 6 reports the results of the activity concentration for ${ }^{226} \mathrm{Ra}$ $(186.21 \mathrm{keV}), \quad{ }^{224} \mathrm{Ra} \quad(240.99 \mathrm{keV}),{ }^{208} \mathrm{Tl} \quad(583.19 \mathrm{keV}), \quad{ }^{214} \mathrm{Bi}$ $(1120.29 \mathrm{keV})$ and ${ }^{40} \mathrm{~K}(1460.83 \mathrm{keV})$ as determined from the application of the equations in Table 4 to the acquired database. For ${ }^{214} \mathrm{Bi}$ $(1120.29 \mathrm{keV})$, the equation in Table 4 yielded activity concentration values compatible to those generated by the formula taking into account the detection efficiency (Fig. 5). For ${ }^{208} \mathrm{Tl}(583.19 \mathrm{keV})$, the equation in Table 3 yielded activity concentration values on average $\sim 8 \%$ lower than those generated by the expression considering the detection efficiency (Fig. 5). However, the same did not happen for other selected $\gamma$-rays emissions associated to beta decay in the ${ }^{238} \mathrm{U}$ series $\left({ }^{214} \mathrm{Bi}-1764.49 \mathrm{keV}\right)$ and ${ }^{232} \mathrm{Th}$ series $\left({ }^{208} \mathrm{Tl}-2614.53 \mathrm{keV} ;{ }^{228} \mathrm{Ac}\right.$ - 911.20 and $968.97 \mathrm{keV}$ ) (Fig. 5). This is possibly related to the detection efficiency decrease when higher $\gamma$-rays energies are involved.
Therefore, the most suitable $\gamma$-rays emissions for providing gross beta information in the ${ }^{238} \mathrm{U}$ and ${ }^{232} \mathrm{Th}$ decay series are ${ }^{214} \mathrm{Bi}(1120.29 \mathrm{keV})$ and ${ }^{208} \mathrm{Tl}(583.19 \mathrm{keV})$, respectively.

Szikszay and Teissedre (1981), among others, reported high ${ }^{222} \mathrm{Rn}$ levels for Villela spring (Águas da Prata city). However, such radionuclide was not monitored in this study. Comparing the data generated by Beato et al. (1999) and Bonotto $(2014,2015)$ with those reported in Table 6 it is possible verify that they differ significantly as a consequence of the use of different analytical techniques, different sampling periods and seasonal variations, among other possible factors. On the other hand, the acquired dataset in this paper for 10 water sources providing from Caxambu and Poços de Caldas spas was compared with that generated for gross beta readings from the gamma spectrometry through a $\mathrm{NaI}(\mathrm{Tl})$ scintillation detector as reported by Bonotto et al. (2009). Both databases are significantly related (Pearson correlation coefficient $=0.60$ ). This confirms the usefulness of the new screening method described here as it helps on assessing radionuclides health risks from drinking water. Obviously, it would be advisable to have a comparison of results with other accepted methods as reported by Jobbágy et al. (2010), however, this is a task for further development due to the costs and time demand involved, among other factors. Despite this, Oliveira et al. (2001), Godoy et al. (2001) and Bonotto (2015) used other conventional methods for measuring ${ }^{228} \mathrm{Ra}$ in several of the waters analyzed in this paper and found values exceeding the WHO (2011) guidance level of $0.1 \mathrm{~Bq} / \mathrm{L}$.

The effect of the storage time of the groundwaters in the Marinellitype beaker was evaluated for 20 samples. Another $\gamma$-rays reading was done at least 30 days after the first measurement. The use of equations in Table 4 allowed generate a new dataset for emissions related to beta 
Table 5

Groundwater samples description and lithological context of the sampling points.

\begin{tabular}{|c|c|c|c|}
\hline Sample no. & Spring/Well & City/State ${ }^{\mathrm{a}}$ & $\begin{array}{l}\text { Lithologic } \\
\text { context }^{\mathrm{b}}\end{array}$ \\
\hline 1 & $7 \mathrm{Bis}$ & São Lourenço/MG & gbg \\
\hline 2 & Sulfurosa & São Lourenço/MG & gbg \\
\hline 3 & Poço 22 & Três Lagoas/MS & SGBP \\
\hline 4 & Alcalina & São Lourenço/MG & gbg \\
\hline 5 & Primavera & São Lourenço/MG & gbg \\
\hline 6 & Ferrruginosa & São Lourenço/MG & gbg \\
\hline 7 & Vichy & São Lourenço/MG & gbg \\
\hline 8 & Roxo Rodrigues & Cambuquira/MG & gsg \\
\hline 9 & $\begin{array}{l}\text { Com. Augusto } \\
\text { Ferreira }\end{array}$ & Cambuquira/MG & gsg \\
\hline 10 & Fernandes Pinheiro & Cambuquira/MG & gsg \\
\hline 11 & Souza Lima & Cambuquira/MG & gsg \\
\hline 12 & Regina Werneck & Cambuquira/MG & gsg \\
\hline 13 & Da. Leopoldina & Caxambu/MG & gqa \\
\hline 14 & Número 6 & São Lourenço/MG & gbg \\
\hline 15 & $\begin{array}{l}\text { Da. Isabel/Conde } \\
\text { Deu }\end{array}$ & Caxambu/MG & gqa \\
\hline 16 & Ernestina Guedes & Caxambu/MG & gqa \\
\hline 17 & D Pedro II & Caxambu/MG & gqa \\
\hline 18 & Viotti & Caxambu/MG & gqa \\
\hline 19 & Poço 21 & Três Lagoas/MS & $\mathrm{BA}$ \\
\hline 20 & Mayrink & Caxambu/MG & gqa \\
\hline 21 & Duque de Saxe & Caxambu/MG & gqa \\
\hline 22 & Poço 4 (LA4) & Lambari/MG & bgm \\
\hline 23 & Poço 2 (LA2) & Lambari/MG & bgm \\
\hline 24 & Poço 1 (LA1) & Lambari/MG & bgm \\
\hline 25 & Poço 3 (LA3) & Lambari/MG & bgm \\
\hline 26 & Ademar de Barros & Termas de Ibirá/SP & BGSG \\
\hline 27 & Carlos Gomes & Termas de Ibirá/SP & BGSG \\
\hline 28 & Saracura & Termas de Ibirá/SP & BGSG \\
\hline 29 & Seixas & Termas de Ibirá/SP & BGSG \\
\hline 30 & São Jorge & Serra Negra/SP & ggm \\
\hline 31 & Samaritana & $\begin{array}{l}\text { Pocinhos do Rio Verde/ } \\
\text { MG }\end{array}$ & nep \\
\hline 32 & Amorosa & $\begin{array}{l}\text { Pocinhos do Rio Verde/ } \\
\text { MG }\end{array}$ & nep \\
\hline 33 & Italianos & Serra Negra/SP & ggm \\
\hline 34 & São Carlos & Serra Negra/SP & ggm \\
\hline 35 & Santa Luzia & Serra Negra/SP & ggm \\
\hline 36 & Santo Agostinho & Serra Negra/SP & ggm \\
\hline 37 & Brunhara & Serra Negra/SP & ggm \\
\hline 38 & Laudo Natel & Serra Negra/SP & ggm \\
\hline 39 & Curie & Águas de Lindóia/SP & ggm \\
\hline 40 & Sant'ana & Serra Negra/SP & ggm \\
\hline 41 & Bioleve & Lindóia/SP & ggm \\
\hline 42 & São Benedito & Lindóia/SP & ggm \\
\hline 43 & Poço 15 & Araçatuba/SP & BA \\
\hline 44 & Poço 40 & Votuporanga/SP & BGSG \\
\hline 45 & Poço 74 & Amambaí/SP & SGBP \\
\hline 46 & Poço60 & $\begin{array}{l}\text { Águas de Santa Bárbara/ } \\
\text { SP }\end{array}$ & SG \\
\hline 47 & Poço 62 & $\begin{array}{l}\text { Águas de Santa Bárbara/ } \\
\text { SP }\end{array}$ & SGBP \\
\hline 48 & Poço 61 & $\begin{array}{l}\text { Águas de Santa Bárbara/ } \\
\text { SP }\end{array}$ & SGBP \\
\hline 49 & Poço 18 & Araçatuba/SP & $\mathrm{BP}$ \\
\hline 50 & Poço 57 & Avaré/SP & BSBP \\
\hline 51 & Poço 55 & Avaré/SP & BGSG \\
\hline 52 & Poço 54 & Avaré/SP & BGSG \\
\hline 53 & Poço 58 & Avaré/SP & SBPP \\
\hline 54 & Poço 56 & Avaré/SP & $\mathrm{BP}$ \\
\hline 55 & Poço 64 & $\begin{array}{l}\text { Bernardino de Campos/ } \\
\text { SP }\end{array}$ & SG \\
\hline 56 & Poço 65 & $\begin{array}{l}\text { Bernardino de Campos/ } \\
\text { SP }\end{array}$ & SGBP \\
\hline 57 & Beleza & Águas de Lindoia/SP & ggm \\
\hline 58 & Poço 67 & $\begin{array}{l}\text { Santa Cruz do Rio } \\
\text { Pardo/SP }\end{array}$ & SG \\
\hline 59 & Poço 28 & Taquaritinga/SP & BA \\
\hline 60 & Poço 41 & Votuporanga/SP & BGSG \\
\hline 61 & Poço 3 & Jaboticabal/SP & BGSG \\
\hline 62 & Poço 4 & Jaboticabal/SP & BGSG \\
\hline 63 & Poço 79 & Presidente Epitácio/SP & $\mathrm{BA}$ \\
\hline
\end{tabular}

Table 5 (continued)

\begin{tabular}{|c|c|c|c|}
\hline Sample no. & Spring/Well & City/State ${ }^{\mathrm{a}}$ & $\begin{array}{l}\text { Lithologic } \\
\text { context }^{\mathrm{b}}\end{array}$ \\
\hline 64 & Frayha & Poços de Caldas/MG & nep \\
\hline 65 & Poço 29 & Taquaritinga/SP & BSBO \\
\hline 66 & Macacos & Poços de Caldas/MG & nep \\
\hline 67 & Poço 11 & Monte Alto/SP & BGSG \\
\hline 68 & Poço 13 & Monte Alto/SP & BSBO \\
\hline 69 & Poço 12 & Monte Alto/SP & BGSG \\
\hline 70 & Poço 38 & Votuporanga/SP & BA \\
\hline 71 & Poço 23 & Santa Ernestina/SP & BGSG \\
\hline 72 & Poço 39 & Votuporanga/SP & BA \\
\hline 73 & Poço 24 & Santa Ernestina/SP & BGSG \\
\hline 74 & Poço 25 & Santa Ernestina/SP & BSBO \\
\hline 75 & Poço 26 & Santa Ernestina/SP & BSBO \\
\hline 76 & Poço 74 & Presidente Prudente/SP & BA \\
\hline 77 & Poço 75 & Presidente Prudente/SP & BGSG \\
\hline 78 & Poço 76 & Presidente Prudente/SP & BGSG \\
\hline 79 & Poço 80 & Presidente Epitácio/SP & BSBO \\
\hline 80 & Poço 53 & Jales/SP & BSBP \\
\hline 81 & Poço 73 & Paraguaçu Paulista/SP & ALL \\
\hline 82 & Poço 77 & Presidente Prudente/SP & SBBPP \\
\hline 83 & Poço 44 & Fernandópolis/SP & BGSG \\
\hline 84 & Poço 45 & Fernandópolis/SP & BGSG \\
\hline 85 & Poço 47 & Fernandópolis/SP & BGSG \\
\hline 86 & Poço 46 & Fernandópolis/SP & BGSG \\
\hline 87 & Poço 71 & Paraguaçu Paulista/SP & BA \\
\hline 88 & Poço 50 & Jales/SP & BGSG \\
\hline 89 & Poço 51 & Jales/SP & BGSG \\
\hline 90 & XV de Novembro & Poços de Caldas/MG & nep \\
\hline 91 & Quisisana & Poços de Caldas/MG & nep \\
\hline 92 & Poço 78 & Presidente Epitácio/SP & $\mathrm{BA}$ \\
\hline 93 & São Roque & Águas de Lindóia/SP & ggm \\
\hline 94 & Poço 72 & Paraguaçu Paulista/SP & BA \\
\hline 95 & Poço 27 & Taquaritinga/SP & BA \\
\hline 96 & Poço 69 & $\begin{array}{l}\text { Santa Cruz do Rio } \\
\text { Pardo/SP }\end{array}$ & SGBO \\
\hline 97 & Poço 66 & $\begin{array}{l}\text { Santa Cruz do Rio } \\
\text { Pardo/SP }\end{array}$ & SGBO \\
\hline 98 & Poço 77 & Sidrolândia/SP & SGBO \\
\hline 99 & Poço 16 & São Carlos/SP & SGBO \\
\hline 100 & Poço 68 & $\begin{array}{l}\text { Santa Cruz do Rio } \\
\text { Pardo/SP }\end{array}$ & SG \\
\hline 101 & Poço 33 & São Pedro/SP & BP \\
\hline 102 & Poço 70 & Sarutaiá/SP & SGBO \\
\hline 103 & Poço 2 & Sertãozinho/SP & SGBP \\
\hline 104 & Villela & Águas da Prata/SP & alk \\
\hline 105 & Vitória & Águas da Prata/SP & alk \\
\hline 106 & Poço 36 & Mirassol/SP & BA \\
\hline 107 & Poço 43 & Votuporanga/SP & BSPI \\
\hline 108 & Poço 42 & Votuporanga/SP & SBBPP \\
\hline
\end{tabular}

gbg = garnet-biotite-gneiss, migmatite, metabasite, pegmatitic veins, quaternary deposits; gsg = garnet schist, gneiss, muscovite quartzite, amphibolite, pegmatitic veins, quaternary deposits; gqa = gneiss, quartzite, alkaline intrusions, quaternary deposits; bgm = biotite gneiss, metabasite, pegmatitic veins, quartzite, muscovite schist, quaternary sediments; ggm = granite, gneiss, migmatite, schist, quartzite, limestone, dolomite; nep = nepheline syenite, phonolites, pyroclastic rocks and volcanic tuffs; alk $=$ alkaline rocks, silicified sandstones, phonolite, diabase; $\mathrm{BA}=$ rocks related to Bauru Group; SG = rocks related to Serra Geral Formation; BP = rocks related to BotucatuPiramboia Formation; BGSG = rocks related to Bauru Group and Serra Geral Formation; $\mathrm{BP}=$ rocks related to Botucatu-Piramboia Formations; SGBP = rocks related to Serra Geral and Botucatu-Pirambóia Formations; BSBP = rocks related to Bauru Group, Serra Geral and Botucatu-Piramboia Formations; SBPP = rocks related to Serra Geral and Botucatu-Piramboia Formations and Passa Dois Group; SBBPP = rocks related to Serra Geral, Botucatu and Piramboia Formations and Bauru and Passa Dois Groups; SGBO = rocks related to Serra Geral and Botucatu Formations; BSBO = rocks related to Bauru Group, Serra Geral and Botucatu Formations; BSPI = rocks related to Bauru Group, Serra Geral and Piramboia Formations; ALL = rocks related to Serra Geral, Botucatu-Piramboia Fm, Bauru, Passa Dois, Tubarão and Paraná Groups.

a $\mathrm{SP}=$ São Paulo, MG = Minas Gerais, MS = Mato Grosso do Sul.

b According to Szikszay and Teissedre (1977), Beato et al. (1999), CPRM (2010), Trouw et al. (2003) and Thedeschi et al. (2015):. 
Table 6

Activity concentration for ${ }^{40} \mathrm{~K}$ and radionuclides belonging to the ${ }^{238} \mathrm{U}$ and ${ }^{232} \mathrm{Th}$ decay series in the groundwater samples analyzed in this paper.

\begin{tabular}{|c|c|c|c|c|c|c|c|}
\hline Sample No. & $\begin{array}{l}{ }^{226} \mathrm{Ra} \\
(\mathrm{Bq} / \mathrm{L})\end{array}$ & $\begin{array}{l}{ }^{224} \mathrm{Ra} \\
(\mathrm{Bq} / \mathrm{L})\end{array}$ & $\begin{array}{l}{ }^{214} \mathrm{Bi}^{\mathrm{a}} \\
(\mathrm{Bq} / \mathrm{L})\end{array}$ & $\begin{array}{l}{ }^{208} \mathrm{Tl}^{\mathrm{b}} \\
(\mathrm{Bq} / \mathrm{L})\end{array}$ & $\begin{array}{l}{ }^{40} \mathrm{~K}^{\mathrm{c}} \\
(\mathrm{Bq} / \\
\mathrm{L})\end{array}$ & $\begin{array}{l}\text { Gross } \\
\text { alpha } \\
(\mathrm{Bq} / \mathrm{L})\end{array}$ & $\begin{array}{l}\text { Gross } \\
\text { beta }^{\mathrm{e}} \\
(\mathrm{Bq} / \mathrm{L})\end{array}$ \\
\hline 1 & 0.64 & 0.67 & 0.12 & 1.18 & 0.12 & 1.31 & 1.42 \\
\hline 2 & 0.94 & 0.70 & 0.51 & 1.14 & 0.50 & 1.64 & 2.15 \\
\hline 3 & 0.14 & 0.78 & $<\mathrm{Lc}$ & 0.77 & $<\mathrm{Lc}$ & 0.92 & 0.77 \\
\hline 4 & 0.80 & 0.53 & $<\mathrm{Lc}$ & 0.52 & 0.16 & 1.33 & 0.68 \\
\hline 5 & 0.74 & 0.41 & 0.43 & 0.41 & 0.40 & 1.15 & 1.24 \\
\hline 6 & $<\mathrm{Lc}$ & 0.33 & $<\mathrm{Lc}$ & 0.30 & 0.09 & 0.33 & 0.39 \\
\hline 7 & 0.58 & 1.06 & 0.20 & 1.49 & 0.48 & 1.64 & 2.17 \\
\hline 8 & $<\mathrm{Lc}$ & 1.04 & $<\mathrm{Lc}$ & 1.73 & $<\mathrm{Lc}$ & 1.04 & 1.73 \\
\hline 9 & $<$ Lc & 1.14 & 0.25 & 1.28 & 0.07 & 1.14 & 1.60 \\
\hline 10 & $<\mathrm{Lc}$ & 1.10 & $<\mathrm{Lc}$ & 0.98 & $<\mathrm{Lc}$ & 1.10 & 0.98 \\
\hline 11 & $<\mathrm{Lc}$ & 1.90 & 1.59 & 2.01 & $<\mathrm{Lc}$ & 1.90 & 3.60 \\
\hline 12 & $<\mathrm{Lc}$ & 0.83 & 0.22 & 0.95 & $<\mathrm{Lc}$ & 0.83 & 1.17 \\
\hline 13 & $<$ Lc & 1.30 & $<\mathrm{Lc}$ & 0.94 & 0.14 & 1.30 & 1.08 \\
\hline 14 & $<\mathrm{Lc}$ & 0.99 & $<\mathrm{LC}$ & 1.21 & $<\mathrm{Lc}$ & 0.99 & 1.21 \\
\hline 15 & $<\mathrm{Lc}$ & 0.58 & $<$ Lc & 0.51 & 0.69 & 0.58 & 1.20 \\
\hline 16 & 1.79 & 3.75 & 0.52 & 4.20 & 1.79 & 5.54 & 6.51 \\
\hline 17 & 0.25 & 3.38 & 0.30 & 4.02 & 0.34 & 3.63 & 4.66 \\
\hline 18 & 0.67 & 1.68 & $<\mathrm{Lc}$ & 1.46 & 0.14 & 2.35 & 1.60 \\
\hline 19 & $<\mathrm{Lc}$ & 1.25 & $<\mathrm{LC}$ & 0.80 & $<$ Lc & 1.25 & 0.80 \\
\hline 20 & 1.10 & 2.34 & 0.13 & 2.70 & 0.20 & 3.44 & 3.03 \\
\hline 21 & 1.09 & 2.62 & $<\mathrm{Lc}$ & 3.40 & 0.67 & 3.71 & 4.07 \\
\hline 22 & 1.48 & 5.12 & $<\mathrm{Lc}$ & 5.91 & $<\mathrm{Lc}$ & 6.60 & 5.91 \\
\hline 23 & 0.55 & 0.82 & $<\mathrm{Lc}$ & 0.88 & $<\mathrm{Lc}$ & 1.37 & 0.88 \\
\hline 24 & $<\mathrm{Lc}$ & 0.16 & $<$ Lc & 0.10 & $<$ Lc & 0.16 & 0.10 \\
\hline 25 & 0.77 & 0.54 & $<\mathrm{Lc}$ & 0.12 & $<$ Lc & 1.31 & 0.12 \\
\hline 26 & $<\mathrm{Lc}$ & 0.45 & $<$ Lc & $<\mathrm{Lc}$ & 0.46 & 0.45 & 0.46 \\
\hline 27 & 0.40 & 1.22 & $<\mathrm{Lc}$ & 0.60 & $<$ Lc & 1.62 & 0.60 \\
\hline 28 & $<$ Lc & 1.39 & $<$ Lc & 1.00 & $<\mathrm{Lc}$ & 1.39 & 1.00 \\
\hline 29 & $<\mathrm{Lc}$ & 4.86 & 0.40 & 4.82 & $<\mathrm{Lc}$ & 4.86 & 5.22 \\
\hline 30 & 0.51 & 2.54 & $<$ Lc & 2.99 & 0.11 & 3.05 & 3.10 \\
\hline 31 & 0.92 & 1.06 & $<$ Lc & 1.00 & 0.19 & 1.98 & 1.19 \\
\hline 32 & 0.50 & 0.69 & $<\mathrm{Lc}$ & 0.77 & $<\mathrm{Lc}$ & 1.19 & 0.77 \\
\hline 33 & 0.13 & 1.06 & $<\mathrm{Lc}$ & 1.02 & 0.06 & 1.19 & 1.08 \\
\hline 34 & 0.38 & 0.54 & $<\mathrm{Lc}$ & 0.28 & $<\mathrm{Lc}$ & 0.92 & 0.28 \\
\hline 35 & $<$ Lc & 0.93 & $<$ Lc & 0.65 & $<$ Lc & 0.93 & 0.65 \\
\hline 36 & 0.80 & 0.71 & $<\mathrm{Lc}$ & 0.56 & $<\mathrm{Lc}$ & 1.51 & 0.56 \\
\hline 37 & $<\mathrm{Lc}$ & 0.72 & $<\mathrm{Lc}$ & 0.69 & $<$ Lc & 0.72 & 0.69 \\
\hline 38 & 0.80 & 2.77 & $<\mathrm{Lc}$ & 2.99 & 0.06 & 3.57 & 3.05 \\
\hline 39 & $<$ Lc & 1.87 & $<\mathrm{Lc}$ & 1.86 & 0.04 & 1.87 & 1.90 \\
\hline 40 & 0.34 & 0.90 & $<\mathrm{Lc}$ & 0.81 & $<\mathrm{Lc}$ & 1.24 & 0.81 \\
\hline 41 & 0.09 & 0.65 & $<\mathrm{Lc}$ & 0.44 & $<\mathrm{Lc}$ & 0.74 & 0.44 \\
\hline 42 & $<\mathrm{Lc}$ & 1.03 & $<$ Lc & 0.65 & $<\mathrm{Lc}$ & 1.03 & 0.65 \\
\hline 43 & $<\mathrm{Lc}$ & 0.73 & $<\mathrm{Lc}$ & 0.44 & 0.10 & 0.73 & 0.54 \\
\hline 44 & 0.94 & 1.58 & $<\mathrm{Lc}$ & 1.64 & 0.04 & 2.52 & 1.68 \\
\hline 45 & 0.27 & 1.04 & $<\mathrm{Lc}$ & 0.69 & $<$ Lc & 1.31 & 0.69 \\
\hline 46 & $<$ Lc & 1.37 & $<$ Lc & 0.92 & $<$ Lc & 1.37 & 0.92 \\
\hline 47 & 0.52 & 0.94 & $<\mathrm{Lc}$ & 0.49 & 0.10 & 1.46 & 0.59 \\
\hline 48 & $<\mathrm{Lc}$ & 0.81 & $<\mathrm{Lc}$ & 0.48 & 0.13 & 0.81 & 0.61 \\
\hline 49 & 1.05 & 2.01 & 0.73 & 2.30 & 0.15 & 3.06 & 3.18 \\
\hline 50 & $<\mathrm{Lc}$ & 0.51 & $<$ Lc & 0.36 & 0.08 & 0.51 & 0.44 \\
\hline 51 & $<\mathrm{Lc}$ & 0.92 & $<$ Lc & 0.53 & $<$ Lc & 0.92 & 0.53 \\
\hline 52 & 0.44 & 1.28 & $<\mathrm{Lc}$ & 1.27 & $<$ Lc & 1.72 & 1.27 \\
\hline 53 & 0.73 & 1.37 & $<\mathrm{LC}$ & 1.35 & $<\mathrm{Lc}$ & 2.10 & 1.35 \\
\hline 54 & 0.38 & 0.37 & $<\mathrm{Lc}$ & 0.22 & $<\mathrm{Lc}$ & 0.75 & 0.22 \\
\hline 55 & 0.59 & 1.17 & $<$ Lc & 0.92 & 0.14 & 1.76 & 1.06 \\
\hline 56 & 0.30 & 0.55 & $<$ Lc & 0.37 & 0.06 & 0.85 & 0.43 \\
\hline 57 & $<$ Lc & 0.47 & $<\mathrm{Lc}$ & 0.24 & $<\mathrm{Lc}$ & 0.47 & 0.24 \\
\hline 58 & 0.36 & 0.88 & 0.10 & 0.85 & $<\mathrm{Lc}$ & 1.24 & 0.95 \\
\hline 59 & $<\mathrm{Lc}$ & 1.28 & 0.11 & 0.99 & 0.05 & 1.28 & 1.15 \\
\hline 60 & $<\mathrm{Lc}$ & 1.19 & $<\mathrm{Lc}$ & 1.06 & $<\mathrm{Lc}$ & 1.19 & 1.06 \\
\hline 61 & 0.35 & 0.36 & $<\mathrm{Lc}$ & 0.19 & $<\mathrm{Lc}$ & 0.71 & 0.19 \\
\hline 62 & 0.73 & 0.63 & $<\mathrm{Lc}$ & 0.36 & 0.23 & 1.36 & 0.59 \\
\hline 63 & $<\mathrm{Lc}$ & 1.32 & $<\mathrm{Lc}$ & 1.17 & $<\mathrm{Lc}$ & 1.32 & 1.17 \\
\hline 64 & $<\mathrm{Lc}$ & 3.78 & 0.35 & 4.09 & 0.09 & 3.78 & 4.53 \\
\hline 65 & $<\mathrm{Lc}$ & 1.11 & 0.37 & 0.79 & $<\mathrm{Lc}$ & 1.11 & 1.16 \\
\hline 66 & 0.38 & 1.12 & $<\mathrm{Lc}$ & 1.20 & $<\mathrm{Lc}$ & 1.50 & 1.20 \\
\hline 67 & 0.14 & 0.31 & $<\mathrm{Lc}$ & 0.11 & $<\mathrm{Lc}$ & 0.45 & 0.11 \\
\hline 68 & 0.28 & 0.50 & $<$ Lc & 0.43 & $<\mathrm{Lc}$ & 0.78 & 0.43 \\
\hline 69 & 0.77 & 0.57 & $<$ Lc & 0.46 & 0.08 & 1.34 & 0.54 \\
\hline 70 & 0.55 & 0.39 & $<$ Lc & 0.30 & 0.04 & 0.94 & 0.34 \\
\hline 71 & $<\mathrm{Lc}$ & 0.64 & $<\mathrm{Lc}$ & 0.69 & $<\mathrm{Lc}$ & 0.64 & 0.69 \\
\hline
\end{tabular}

Table 6 (continued)

\begin{tabular}{|c|c|c|c|c|c|c|c|}
\hline Sample No. & $\begin{array}{l}{ }^{226} \mathrm{Ra} \\
(\mathrm{Bq} / \mathrm{L})\end{array}$ & $\begin{array}{l}{ }^{224} \mathrm{Ra} \\
(\mathrm{Bq} / \mathrm{L})\end{array}$ & $\begin{array}{l}{ }^{214} \mathrm{Bi}^{\mathrm{a}} \\
(\mathrm{Bq} / \mathrm{L})\end{array}$ & $\begin{array}{l}{ }^{208} \mathrm{Tl}^{\mathrm{b}} \\
(\mathrm{Bq} / \mathrm{L})\end{array}$ & $\begin{array}{l}{ }^{40} \mathrm{~K}^{\mathrm{c}} \\
(\mathrm{Bq} / \\
\mathrm{L})\end{array}$ & $\begin{array}{l}\text { Gross } \\
\text { alpha }^{\text {d }} \\
(\mathrm{Bq} / \mathrm{L})\end{array}$ & $\begin{array}{l}\text { Gross } \\
\text { beta }^{\text {e }} \\
(\mathrm{Bq} / \mathrm{L})\end{array}$ \\
\hline 72 & 0.64 & 0.67 & 0.26 & 0.78 & $<\mathrm{Lc}$ & 1.31 & 1.04 \\
\hline 73 & 0.70 & 0.58 & 0.13 & 0.36 & 0.10 & 1.28 & 0.59 \\
\hline 74 & 0.50 & 0.60 & $<\mathrm{Lc}$ & 0.55 & 0.07 & 1.10 & 0.62 \\
\hline 75 & 0.21 & 0.40 & $<\mathrm{Lc}$ & 0.29 & 0.12 & 0.61 & 0.41 \\
\hline 76 & 0.33 & 0.46 & $<\mathrm{Lc}$ & 0.38 & 0.05 & 0.79 & 0.43 \\
\hline 77 & 0.54 & 0.75 & $<\mathrm{Lc}$ & 0.48 & 0.05 & 1.29 & 0.53 \\
\hline 78 & 0.44 & 0.67 & $<\mathrm{Lc}$ & 0.70 & $<\mathrm{Lc}$ & 1.11 & 0.70 \\
\hline 79 & 0.81 & 1.08 & $<\mathrm{Lc}$ & 0.98 & 0.07 & 1.89 & 1.05 \\
\hline 80 & 0.92 & 1.58 & 0.37 & 1.77 & 0.07 & 2.50 & 2.21 \\
\hline 81 & 0.53 & 0.82 & $<\mathrm{Lc}$ & 0.80 & $<\mathrm{Lc}$ & 1.35 & 0.80 \\
\hline 82 & 0.60 & 0.36 & $<\mathrm{Lc}$ & 0.41 & $<\mathrm{Lc}$ & 0.96 & 0.41 \\
\hline 83 & 0.64 & 0.37 & $<\mathrm{Lc}$ & 0.33 & 0.09 & 1.01 & 0.42 \\
\hline 84 & 0.44 & 0.39 & $<\mathrm{Lc}$ & 0.36 & 0.05 & 0.83 & 0.41 \\
\hline 85 & $<\mathrm{Lc}$ & 0.70 & $<\mathrm{Lc}$ & 0.70 & $<\mathrm{Lc}$ & 0.70 & 0.70 \\
\hline 86 & $<\mathrm{Lc}$ & 0.84 & 0.14 & 0.86 & 0.07 & 0.84 & 1.07 \\
\hline 87 & $<\mathrm{Lc}$ & 0.84 & $<\mathrm{Lc}$ & 0.73 & $<\mathrm{Lc}$ & 0.84 & 0.73 \\
\hline 88 & 0.32 & 0.50 & $<\mathrm{Lc}$ & 0.67 & $<\mathrm{Lc}$ & 0.82 & 0.67 \\
\hline 89 & 0.70 & 1.14 & 0.14 & 1.38 & 0.07 & 1.84 & 1.59 \\
\hline 90 & 0.29 & 1.33 & 0.21 & 1.84 & 0.05 & 1.62 & 2.10 \\
\hline 91 & 0.47 & 0.84 & 0.47 & 1.17 & $<\mathrm{Lc}$ & 1.31 & 1.64 \\
\hline 92 & $<\mathrm{Lc}$ & 0.88 & 0.28 & 0.70 & 0.12 & 0.88 & 1.10 \\
\hline 93 & 0.85 & 0.47 & 1.32 & 0.40 & $<\mathrm{Lc}$ & 1.32 & 1.72 \\
\hline 94 & $<\mathrm{Lc}$ & 0.56 & $<\mathrm{Lc}$ & 0.52 & $<\mathrm{Lc}$ & 0.56 & 0.52 \\
\hline 95 & 0.64 & 0.51 & $<\mathrm{Lc}$ & 0.64 & $<\mathrm{Lc}$ & 1.15 & 0.64 \\
\hline 96 & $<\mathrm{Lc}$ & 1.09 & 0.23 & 1.01 & $<\mathrm{Lc}$ & 1.09 & 1.24 \\
\hline 97 & 0.52 & 0.40 & $<\mathrm{Lc}$ & 0.41 & $<\mathrm{Lc}$ & 0.92 & 0.41 \\
\hline 98 & $<\mathrm{Lc}$ & 0.62 & $<\mathrm{Lc}$ & 0.78 & $<\mathrm{Lc}$ & 0.62 & 0.78 \\
\hline 99 & 0.56 & 0.57 & $<\mathrm{Lc}$ & 0.51 & $<\mathrm{Lc}$ & 1.13 & 0.51 \\
\hline 100 & $<\mathrm{Lc}$ & 1.29 & 0.16 & 1.14 & $<\mathrm{Lc}$ & 1.29 & 1.30 \\
\hline 101 & $<\mathrm{Lc}$ & 1.08 & $<\mathrm{Lc}$ & 1.05 & 0.06 & 1.08 & 1.11 \\
\hline 102 & 0.44 & 0.62 & 0.09 & 0.50 & $<\mathrm{Lc}$ & 1.06 & 0.59 \\
\hline 103 & 0.66 & 0.54 & $<\mathrm{Lc}$ & 0.73 & 0.04 & 1.20 & 0.77 \\
\hline 104 & 0.34 & 0.19 & $<\mathrm{Lc}$ & 0.15 & 0.07 & 0.53 & 0.22 \\
\hline 105 & 1.45 & 0.72 & $<\mathrm{Lc}$ & 0.62 & 0.12 & 2.17 & 0.74 \\
\hline 106 & 0.34 & 0.64 & $<\mathrm{Lc}$ & 0.46 & 0.10 & 0.98 & 0.56 \\
\hline 107 & 0.68 & 0.51 & $<\mathrm{Lc}$ & 0.63 & $<\mathrm{Lc}$ & 1.19 & 0.63 \\
\hline 108 & $<\mathrm{Lc}$ & 0.93 & $<\mathrm{Lc}$ & 1.25 & 0.08 & 0.93 & 1.33 \\
\hline
\end{tabular}

a $1120.29 \mathrm{keV}$.

b $583.19 \mathrm{keV}$.

c $1460.83 \mathrm{keV}$.

d $\left({ }^{226} \mathrm{Ra}+{ }^{224} \mathrm{Ra}\right)$.

e $\left({ }^{214} \mathrm{Bi}+{ }^{208} \mathrm{Tl}+{ }^{40} \mathrm{~K}\right)$.

decays in the ${ }^{238} \mathrm{U}$ and ${ }^{232} \mathrm{Th}$ series. The data comparison of both readings indicated not coincident results. Possible explanation could be related to eventual radon leakage through the beaker wall (Zereshki, 1983). Also, deposition of radionuclides adsorbed to fine/colloidal particles in the container wall/bottom, yielding gamma emissions that not interact with the detector. "Radioactive Disequilibrium" against "Radioactive Equilibrium" readings showed, for ${ }^{214} \mathrm{Bi}(1120.29 \mathrm{keV})$, higher values in the second case in practically all samples (17), as expected from theoretical considerations (Ivanovich and Harmon, 1992). However, for ${ }^{208} \mathrm{Tl}(583.19 \mathrm{keV})$, it happened for 11 samples, which may be a consequence of the more susceptibility of Th for adsorption into colloidal particles (Langmuir and Herman, 1980). Future experiments are planned in order to better investigate these and other possible processes involved with the storage time of the water samples.

The gross alpha activity estimated from $\gamma$-rays of ${ }^{226} \mathrm{Ra}(186.21 \mathrm{keV})$ and ${ }^{224} \mathrm{Ra}(240.99 \mathrm{keV})$ varied between 0.16 and $6.60 \mathrm{~Bq} / \mathrm{L}$ (Table 5). The WHO (2011) guideline reference value of $0.5 \mathrm{~Bq} / \mathrm{L}$ was not exceeded only for 5 groundwater samples (4.6\%). The gross beta activity estimated from $\gamma$-rays of ${ }^{214} \mathrm{Bi}(1120.29 \mathrm{keV}),{ }^{208} \mathrm{Tl}(583.19 \mathrm{keV})$ and ${ }^{40} \mathrm{~K}(1460.83 \mathrm{keV})$ varied between 0.10 and $6.51 \mathrm{~Bq} / \mathrm{L}$ (Table 6$)$. In this case, the WHO (2011) guideline reference value of $1 \mathrm{~Bq} / \mathrm{L}$ was not exceeded for 60 groundwater samples $(\sim 56 \%)$. In general, the gross beta measurements held elsewhere include a contribution from ${ }^{40} \mathrm{~K}$. However, potassium is an essential element for humans and is absorbed 
$\mathrm{Bi}-214(1120.29 \mathrm{keV})$

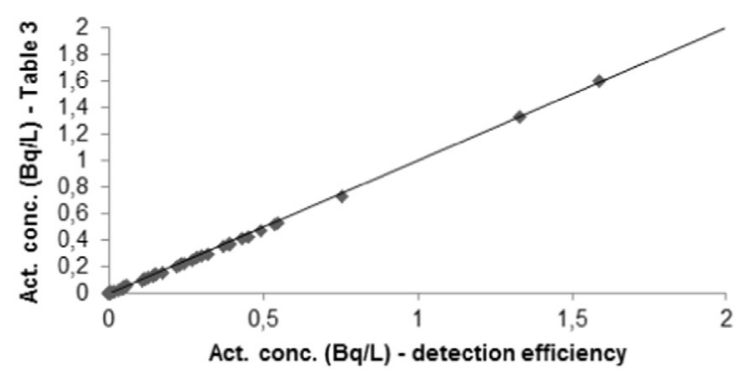

Bi-214 (1764.49 keV)
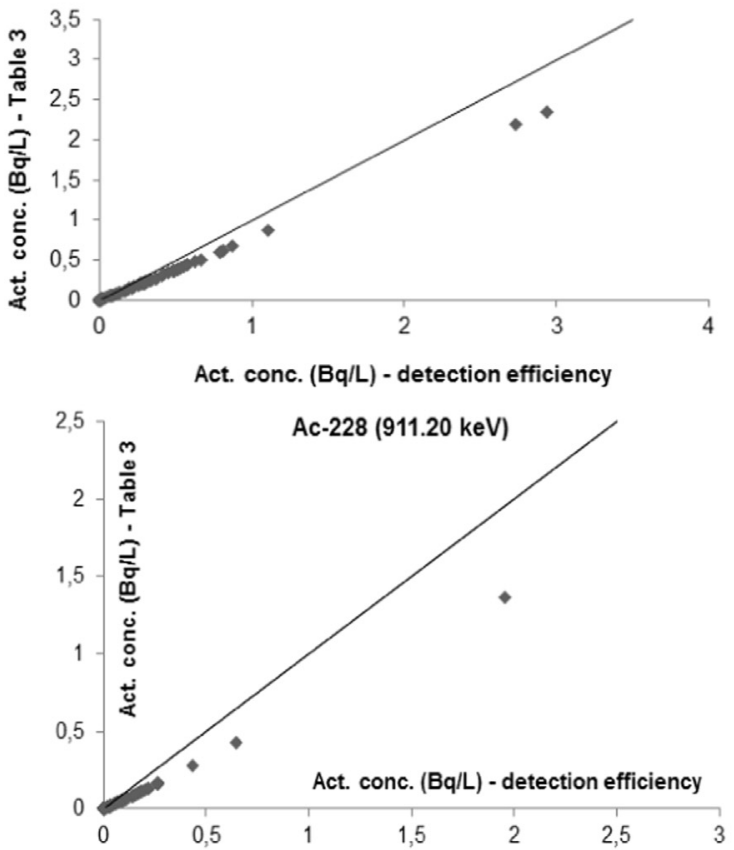

Tl-208 (583.19 keV)

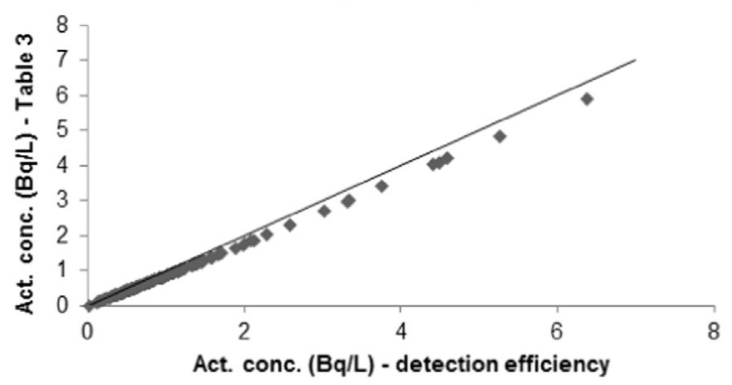

TI-208 (2614.53 keV)

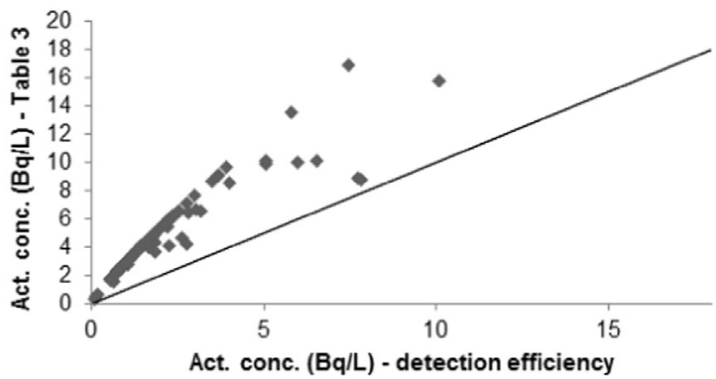

Ac-228 (968.97 keV)

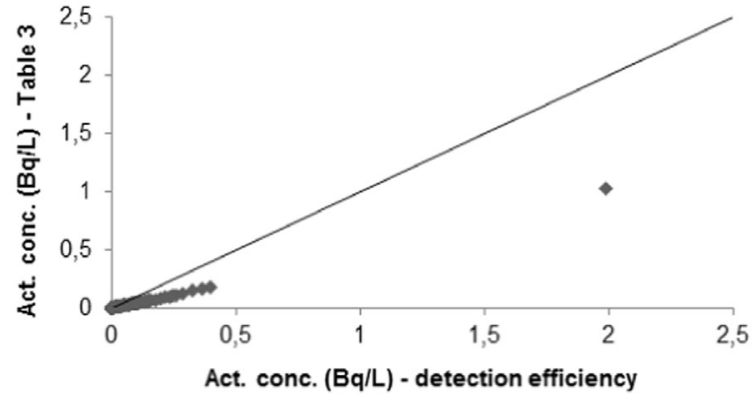

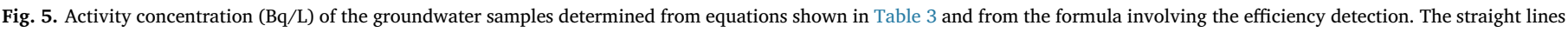
represent the equilines for each $\gamma$-rays energy.

mainly from ingested food. WHO (2011) suggests that if the screening level of $1 \mathrm{~Bq} / \mathrm{L}$ for gross beta is exceeded, the contribution of ${ }^{40} \mathrm{~K}$ to beta activity should be subtracted following a separate determination of total potassium. The beta activity of ${ }^{40} \mathrm{~K}$ is $27.9 \mathrm{~Bq} / \mathrm{g}$ of stable potassium, which is the factor that should be used to calculate the beta activity due to ${ }^{40} \mathrm{~K}$ (WHO, 2011). But the method described in this paper allows determine directly the ${ }^{40} \mathrm{~K}$ contribution to the gross beta radioactivity. The data reported in Table 5 indicate that such contribution is greatly variable, covering the whole range of $0-100 \%$. Therefore, the gross alpha screening level is much more exceeded in the water sources analyzed compared to the gross beta guideline reference value.

Despite the solubility of uranium is known to be higher than that of thorium (Langmuir, 1978), the gross alpha data indicate a major contribution of ${ }^{224} \mathrm{Ra}\left({ }^{232} \mathrm{Th}\right.$ decay series) relatively to ${ }^{226} \mathrm{Ra}\left({ }^{238} \mathrm{U}\right.$ decay series) to the radiological characterization of the water sources analyzed. The ${ }^{226} \mathrm{Ra}$ activity concentration was higher than the ${ }^{224} \mathrm{Ra}$ activity concentration in only $\sim 17 \%$ of the groundwaters. Radium has one oxidation state in natural systems, i.e. Ra(II), behaving, in many respects, like other alkaline earth elements. It forms strong complexes with sulfate and carbonate and weak complexes with nitrate and chloride (Langmuir and Reise, 1985). Other factors like pH, Eh and presence of organic matter may also affect its migration to water bodies.

Potential health hazards from radium isotopes in consuming water have been considered worldwide, with several countries adopting the guideline activity concentration for drinking water quality recommended by WHO (2011). The geological factor is essential to its incorporation into the liquid phase. Samples providing from fractured aquifers in crystalline terrains (for instance, in the municipalities of Caxambu, Lambari, Cambuquira, Poços de Caldas and Serra Negra) exhibited enhanced levels of gross alpha and beta activities that are confirmed by the ${ }^{226} \mathrm{Ra}$ and ${ }^{228} \mathrm{Ra}$ analysis held by Oliveira et al. (2001), Godoy et al. (2001) and Bonotto (2015) in several of the water sources analyzed in this paper. The regional geology of those towns shows the presence of gneisses, migmatites, metasedimentary sequences, pegmatites veins, traquites, syenites, and alkaline brecchias, especially in the area around the spring waters park in Caxambu, where alkaline veins were reported by Beato et al. (1999). Generally speaking, groundwaters collected from aquifer systems in Paraná Basin presented lower gross alpha and beta levels when compared to those mentioned, despite some exceptions were observed, for instance, in the municipalities of Termas de Ibirá, Jales and Araçatuba.

The technique described in this paper highlights the ${ }^{224} \mathrm{Ra}\left({ }^{232} \mathrm{Th}\right.$ decay series) contribution to the gross alpha activities. It increases the activity value for almost every groundwater sample, thus, implying on values above the WHO (2011) screening level. The ${ }^{226} \mathrm{Ra}$ data reported by Bonotto (2015) indicated values exceeding the WHO (2011) guideline reference value of $1 \mathrm{~Bq} / \mathrm{L}$ in only four water sources. Therefore, radiation dose calculations integrating the ${ }^{226} \mathrm{Ra}$ and ${ }^{228} \mathrm{Ra}$ activity 
concentration data as reported by Bonotto (2015) indicated little ${ }^{226} \mathrm{Ra}$ influence on the values exceeding the WHO individual dose criterion of $0.1 \mathrm{mSv} /$ year. However, a novel scenario arises from this study if the ${ }^{224} \mathrm{Ra}$ levels are included in the calculation, suggesting additional radiological surveys for Brazilian groundwaters.

\section{Conclusion}

The $\gamma$-rays analysis performed with hyper-pure germanium detector (HPGe) is an alternative methodology to determine gross alpha and beta activity in waters. It was successfully used for generating screening values in groundwater samples providing from different aquifer systems in the Brazilian states of São Paulo, Minas Gerais and Mato Grosso do Sul. The water sources analyzed exhibit very large differences on the chemical composition, thus, justifying its application inclusive for highly saline matrices whose evaluation is difficult by other techniques. The adoption of a single reading in a unique spectrometric system for simultaneous beta and alpha data acquisition is one of the greatest advantages of the proposed method. The high spectral resolution of the HPGe gamma detector expanded the possibilities of calibration, allowing the identification and delimitation of peaks associated to natural radionuclides commonly present in the waters like ${ }^{40} \mathrm{~K}$ and those belonging to the ${ }^{238} \mathrm{U}$ and ${ }^{232} \mathrm{Th}$ decay series. However, anthropogenic radionuclides can be also easily identified in the $\gamma$-rays spectra, for instance, ${ }^{235} \mathrm{U}$ providing from the nuclear cycle and introduced in the water bodies. Other procedures like alpha spectrometry require the use of steps involving the total evaporation of the sample and deposition of the dry residue on a planchet, which have a huge potential of causing material loss and absorption of alpha particles by the residue itself due to the salinity of the matrices. The method described also abolishes the use of chemicals such as $\mathrm{Fe}(\mathrm{OH})_{3}$ and $\mathrm{BaSO}_{4}$ that are often needed by others. Thus, it does not demand more sophisticated and time-consuming procedures, is cheaper and a friendly environment alternative for gross alpha and beta characterization in waters. Additionally, compared to other methods, there is an enormous advantageous on saving efforts for identifying the potential alpha and beta emitters when the screening values are exceeded as they are directly identified in the $\gamma$-rays spectra. Consequently, remedial actions to reduce dose can be taken immediately without demanding longer duration laboratory essays.

\section{Acknowledgments}

FAPESP (Foundation Supporting Research in São Paulo State) and CNPq (National Council for Scientific and Technologic Development) in Brazil are thanked by grants No. 2015/03974-1, 2016/03054-2 and 301462/2011-9 that financed this study. UNESPetro (Geosciences Center Applied to Petroleum) is also thanked for allowing access to the $\gamma$-rays spectrometer with HPGe detector. Two anonymous reviewers are greatly thanked by helpful comments that improved the readability of the manuscript.

\section{References}

ANA (Agência Nacional de Águas), 2013. Mapa de afloramento dos aquíferos do Brasil: disponibilidade de águas subterrâneas nos principais sistemas aquíferos. 〈http:// arquivos.ana.gov.br/institucional/sge/CEDOC/Catalogo/2014/ MapaAreasDeAfloramentoDosAquiferosDoBrasil.pdf $\rangle$.

Barbosa, E.Q., 2016. Calibração de detectors cintiladores e sua aplicação em medidas radiométricas, (MS Dissertation). UNESP-São Paulo State University, Rio Claro, pp. 191.

Beato, D.A., Oliveira, F.A., Viana, H.S., 1999. Projeto Circuito das Águas do Estado de Minas Gerais. CPRM, Belo Horiz. 142.

Bentley, H.W., Phillips, F.M., Davis, S.N., $1986 .{ }^{36} \mathrm{Cl}$ in the terrestrial environment. In: Fritz, P., Fontes, J.Ch (Eds.), Handbook of Environmental Geochemistry. Elsevier, New York, pp. 422-475.

Bonotto, D.M., 2014. ${ }^{222} \mathrm{Rn},{ }^{220} \mathrm{Rn}$ and other dissolved gases in mineral waters of southeast Brazil. J. Environ. Radioact. 132, 21-30.

Bonotto, D.M., 2015. ${ }^{226} \mathrm{Ra}$ and ${ }^{228} \mathrm{Ra}$ in mineral waters of southeast Brazil. Environ.
Earth Sci. 74, 839-853

Bonotto, D.M., Bueno, T.O., 2008. The natural radioactivity in Guarani aquifer groundwater, Brazil. Appl. Radiat. Isot. 66, 1507-1522.

Bonotto, D.M., 2011. Natural radionuclides in major aquifer systems of the Paraná sedimentary basin, Brazil. Appl. Radiat. Isot. 69, 1572-1584.

Bonotto, D.M., Bueno, T.O., Tessari, B.W., Silva, A., 2009. The natural radioactivity in water by gross alpha and beta measurements. Radiat. Meas. 44, 92-101.

Cantor, K.P., 1997. Drinking water and cancer. Cancer Causes Control 8, 292-308.

Campos Neto, M.C., 1991. A porção ocidental da faixa Alto do Rio Grande: ensaio de evolução tectônica. Ms. Dissertation USP, São Paulo, p. 210.

Campos Neto, M.C., Perrotta, M.M., Peloggia, A.U., Figueiredo, M.C.H., 1990. A porção ocidental da faixa Alto do Rio Grande (SP-MG). In: SBG (Sociedade Brasileira de Geologia) (Ed.), Anais 36 Congresso Brasileiro de Geologia. SBG, Natal, pp. 2615-2630.

Chu, S.Y.F., Ekström, L.P., Firestone, R.B., 1999. The Lund/LBNL Nuclear Data Search $\langle$ http://nucleardata.nuclear.lu.se/nucleardata/toi/index.asp〉.

Clark, K.F., 1989. Mineral composition of rocks. In: Carmichael, R.S. (Ed.), Practical Handbook of Physical Properties of Rocks and Minerals. CRC Press, Boca Raton, pp. $1-137$.

CPRM (Brazilian Geological Survey), 2010. SIAGAS-Information System of Groundwaters. 〈http://siagasweb.cprm.gov.br/layout/pesquisacomplexa.php〉.

Currie, L.A., 1968. Limits for qualitative detection and quantitative determination. Anal. Chem. 40, 586-593.

Faure, G., Mensing, T.M., 2005. Isotopes: Principles and Applications, 3rd ed. John Wiley \& Sons, Inc, Hoboken, New Jersey, pp. 776.

Fernandes, L.A., 2004. Mapa litoestratigráfico da parte oriental da Bacia Bauru (PR, SP e MG), escala 1:1.000.000. Bol. Parana. De. Geociênc. 55, 53-66.

Godoy, J.M., Amaral, E.C.S., Godoy, M.L.D.P., 2001. Natural radionuclides in Brazilian mineral water and consequent doses to the population. J. Environ. Radioact. 53, $175-182$.

Hasui, Y., Oliveira, M.A.F., 1984. Província Mantiqueira - setor central. In: Almeida, F.F.M., Hasui, Y. (Eds.), O Pré-Cambriano do Brasil, 1st ed. Edgard Blücher, São Paulo, pp. 308-344.

Heier, K.S., Billings, G.K., 1969. Potassium. In: Wedepohl, K.H. (Ed.), Handbook of Geochemistry 2 Springer-Verlag, New York (ch. 19).

Hopke, P.K., Borak, T.B., Doull, J., Cleaver, J.E., Eckerman, K.F., Gunderson, L.C.S., Harley, N.H., Hess, C.T., Kinner, N.E., Kopecky, K.J., McKone, T.E., Sextro, R.G., Simon, S.L., 2000. Health risks due to radon in drinking water. Environ. Sci. Technol. 34, 921-926.

Hossain, I., Sharip, N., Viswanathan, K.K., 2012. Efficiency and resolution of HPGe and $\mathrm{NaI}(\mathrm{Tl})$ detectors using gamma-ray spectroscopy. Sci. Res. Essays 7 (1), 86-89.

Iritani, M.A., Ezaki, S., 2012. As águas subterrâneas do Estado de São Paulo, 3rd ed. Secretaria de Estado do Meio Ambiente - SMA, São Paulo, pp. 104.

Ivanovich, M., Harmon, R.S., 1992. Uranium Series Disequilibrium: Applications to Environmental Problems, 2nd ed. Clarendon Press, Oxford.

Jobbágy, V., Wätjen, U., Meresova, J., 2010. Current status of gross alpha/beta activity analysis in water samples: a short overview of methods. J. Radioanal. Nucl. Chem. 286, 393-399.

Jobbágy, V., Meresova, J., Wätjen, U., 2014. Critical remarks on gross alpha/beta activity analysis in drinking water: conclusions from a European interlaboratory comparison. Appl. Radiat. Isot. 87, 429-434.

Jobbágy, V., Meresova, J., Dupuis, E., Kwakman, P., Altzitzoglou, T., Rozkov, A., Hult, M., Emteborg, H., Wätjen, U., 2015. Results of a European interlaboratory comparison on gross alpha/beta activity determination in drinking water. J. Radioanal. Nucl. Chem. 306, 325-331.

Langmuir, D., 1978. Uranium solution-mineral equilibria at low temperatures with applications to sedimentary ore deposits. Geochim. Cosmochim. Acta 42, 547-569.

Langmuir, D., Herman, J.S., 1980. The mobility of thorium in natural waters at low temperatures. Geochim. Cosmochim. Acta 44, 1753-1766.

Langmuir, D., Reise, A.C., 1985. The thermodynamic properties of radium. Geochim. Cosmochim. Acta 49, 1593-1601.

Milani, E.J., Melo, J.H.G., Souza, P.A., Fernandes, L.A., França, A.B., 2007. Bacia do Paraná. Bol. De. Geociênc. da Petrobras 15 (2), 265-287.

NBL (New Brunswick Laboratory), 1999. Certified Reference Materials Catalog. United States Department of Energy, Argonne, Illinois, pp. 53-59.

Oliveira, J. de, Mazzilli, B.P., Costa, P., da, Tanigava, P.A., 2001. Natural radioactivity in Brazilian bottled mineral waters and consequent doses. J. Radioanal. Nucl. Chem. 249 (1), 173-176.

Pearce, A., 2008. Recommended Nuclear Decay Data. National Physical Laboratory Hampton Road, Teddington, UK (NPL Report IR 6).

Rodrigues, J.L., Kastner, G.F., Ferreira, A.V., 2011. Determinação de curvas de eficiência para detector HPGe em diferentes geometrias de contagem. In: ABEN (Associação Brasileira de Energia Nuclear) (Ed.) Proceedings 2011 International Nuclear Atlantic Conference - INAC 2011. ABEN, Belo Horizonte, pp. 1-11.

Rogers, J.J.W., Adams, J.A.S., 1969a. Uranium. In: Wedepohl, K.H. (Ed.), Handbook of Geochemistry 4 Springer-Verlag, New York (ch. 92).

Rogers, J.J.W., Adams, J.A.S., 1969b. Thorium. In: Wedepohl, K.H. (Ed.), Handbook of Geochemistry 4 Springer-Verlag, New York (ch. 90).

Schneider, R.L., Muhlmann, H., Tommasi, E., Medeiros, R.A., Daemon, R.F., Nogueira, A.A., 1974. Revisão estratigráfica da Bacia do Paraná. In: SBG (Sociedade Brasileira de Geologia) (Ed.), Anais 28 Congresso Brasileiro de Geologia 1. SBG, Porto Alegre, pp. 41-65.

Soares, P.C., 1972. O limite glacial-pós-glacial do Grupo Tubarão no estado de São Paulo. An. Acad. Bras. Ciênc 44, 333-342.

Szikszay, M., Teissedre, J.M., 1977. Fontes da Estância de Águas da Prata, Estado de São Paulo. Bol. IG USP 8, 83-96. 
Szikszay, M., Teissedre, J.M., 1981. Águas minerais no Estado de São Paulo: características físico-químicas e classificação. Bol. IG USP 12, 11-22.

Thedeschi, M.F., Vieira, P.L.N.C.R., Nomo, T.A., 2015. Projeto fronteiras de Minas Gerais Folha Caldas/Poços de Caldas, escala: 1:100.000. UFMG-Universidade Federal de Minas Gerais. Belo Horiz. 78.

Thorton, I., 1983. Applied Environmental Geochemistry. Academic Press, London, pp. 501.

Trouw, R.A.J., Ribeiro, A., Paciullo, F.V.P., 2003. Geologia da Folha Caxambu 1:100.000.
In: Pedrosa Soares, C.A., Noce, M.A., Trouw, R.A.J., Heilbron, M. (Eds.), Geologia da Folha Caxambu 1:100.000. COMIG-Companhia Mineradora de Minas Gerais, 1st ed. Belo Horizonte, pp. 120-152.

WHO (World Health Organization), 2011. Guidelines for Drinking Water Quality: Radiological Aspects, 4th ed. WHO Press, Geneva.

Zereshki, A., 1983. The solution of ${ }^{222}$ Rn by groundwaters (Ph.S. thesis). Bath University, Bath, pp. 244. 